\title{
PROCEDURAL DEVICES FOR SIMPLIFYING LITIGATION STEMMING FROM A MASS TORT
}

A ship explodes in harbor, a dam breaks, a trestle collapses under the weight of a train. fire envelops a circus tent-each of these accidents may cause extensive loss of life, personal injury, and property damage. Hundreds or thousands of suits resulting from such a "mass tort" are usually instituted in the ensuing days of confusion. ${ }^{1}$ Both claimants and defendants may find themselves in a litigatory jungle. If there is more than one possible defendant, the issue of ultimate responsibility may be bandied to and fro among the allegen tort-feasors. ${ }^{2}$ Insurance companies may be subrogated into the legal free-forall. Judgments against some defendants will not bind others." And where the United States is a defendant, a state court's judgment cannot bind it at all. 5

Even when there is only one defendant, trial strategy may prompt some plaintiffs to sue in federal court or in states other than the one in which the tort was committed. ${ }^{e}$ Consequently, litigation of issues arising from a "mass tort" may proceed in many jurisdictions at once. This process is time-consuming and costly. Different courts, both state and federal, may reach diver-

1. In one ship explosion case about three hundred suits were brought by approximately eighty-five hundred claimants. In re Texas City Disaster Litigation. 197 F.2d 771 (5th Cir. 1952), aff'd sub nom. Dalehite v. Cnited States, 346 U.S. 15 (1953). In another explosion case, death, injury, or damage was caused to some eight thousand persons. About two years after the accident some seven thousand clains had been filed. Pennsylvania R.R. v. United States, 111 F. Supp. 80 (D.N.J. 1953). In a case involving a dam break 712 actions were filed, involving some three thousand claims. Clark v. United States, 13 F.R.D. 342 (D. Ore. 1952).

2. See, e.g., In re Texas City Distaster Litigation, stora note 1; Pennsylvania R.R. v. United States, supra note 1.

3. See In re Texas City Distaster Litigation, sipra note 1; Metropolitan Casualty Ins. Co. of N.Y. v. Lehigh Talley R.R., 94 N.J.L. 236, 109 Atl. 743 (Ct. Err. \& App. 1920 ) ; communication to the Yale L.LW Jouri.u from Stuart W. Thayer of Corington \& Burling, Washington, D.C. counsel for the plaintiff in the Teras City litigation tafore the Supreme Court, dated April 15, 1953, in Yale Law Library.

4. It is the general rule that a judgment binds only the impleaded parties and their privies. McCollum v. Smith, 233 N.C. 10, 62 S.E.2d 483 (1950). See also note 29 infra.

5. The Federal Tort Claims Act specifically grarits to the federal district courts sitting without a jury and subject to the Rules of Civil Prucedure, exclusive original jurisdiction over all tort claims which the Act permits to be instituted against the Cnited States. 60 STAT. S42, 28 U.S.C. $\$ 1346$ (b) (1946).

6. See, e.g., Pennsylvania R.R. v. United States, 111 F. Supp. 80 (D.N.J. 19531. See also note 8 infra.

7. See Pennsylvania R.R. v. United States, supra note 6 .

8. See First State Bank v. Chicago, R.I. \& P.R.R., 63 F.2d 585, 590 (8th Cir. 1933) ("The avoidance of unnecessary suits should be much desired by litigants and taspayers.") Also see note 1 supra. 
gent decisions. ${ }^{9}$ Conflicts of law questions are presented. Test cases may be carried to the highest accessible courts. ${ }^{10}$ Many legal theories will be espoused. Through this melange of litigation, plaintiffs must thread their way to success or failure, while defendants do battle on all fronts. ${ }^{11}$

Defendants especially desire to avoid extensive litigation. In any case the proclivity of juries to favor plaintiffs augurs ill for defendant's victory. ${ }^{12}$ And in mass tort situations, the expense of litigating a multitude of claims over a wide geographic area may force settlement whenever possible. Defendants therefore seek to simplify their task by having claims consolidated..$^{13}$

Plaintiffs, however, may object to consolidation. Many claimants will prefer to bring their actions separately. ${ }^{14}$ To be sure, consolidating would cut

9. In one instance, a number of actions for damage and injury arose out of an explosion. In Waters-Pierce Oil Co. v. Purrows, 77 Ark. 74. 96 S.W. 336 (1905), the court sustained a verdict against the oil company. But in Waters-Pierce Oil Co v. Kniscl, 79 Ark. 608, 96 S.W. 342 (1906), arising out of the same accident but in which the facts were more fully developed than in the Burrozis case, the court granted judgment for the oil company. See also Waters-Pierce Oil Co. v. Van Elderen, 84 Ark. 555, 106 S.W. 947 (1907).

10. E.g., Dalehite v. United States, 346 U.S. 15 (1953).

11. Maintenance of public good will may lead a defendant to settle claims against it. even where its liability is in doubt. Nevertheless, the amount of individual damages may be litigated if the sum demanded appears to be excessive. And litigation of all claims may be required if the defendant's assets are insufficient to cover the aggregate amount of the claims filed.

12. See James, Function of Judge and Jury in Negligence Cases, 58 YAt.E L.J. 66). 686-7 (1949). The tendency of juries to favor the plaintiff may result from the fact that most people believe that the large corporation is adequately insured through outside in surers or is self-insured. Thus they may resolve all doubts in favor of the individual and against the impersonal entity. This factor is important in any discussion of mass tort?. since the majority of defendants in such situations are large corporations, municipalitics, states, or the Federal Government.

13. Consolidation is used at this juncture to mean any procedure for simplification of multiple suits into one proceeding. The term may also be used to denote a specific procedure for joining separate actions by multiple claimants. See pages 516-19 infra. In its most technical sense, consolidation refers to the union of two causes of action brought by the same plaintiff against the same defendant. See Fire Ins. Co. v. Chesapeale \& O. Ry., 4 F. Supp. 25, 29 (E.D. Ky. 1933).

14. Or if he chooses, the plaintiff may in many instances intervene in an action which has already been instituted. See FrD. R. Civ. P. 24; Cameron v. The President \& Fellows of Harvard College, 157 F.2d 993 (1st Cir. 1946) ; Champ v. Atkins, 128 F.2d 601 (D.C. Cir. 1942) ; Knapp v. Hankins, 106 F. Supp. 43 (E.D. Ill. 1952).

But in the tort situation, intervention will be at the court's discretion, absent a statute which makes it a right. In such a situation, intervention is usually denied when the adjudication of the original parties' rights will be unduly prejudiced or clelayed thereby. Alleil Calculators, Inc. v. National Cash Register Co., 322 U.S. 137 (19.44).

Where permissive intervention is allowed, it is necessary for the would-be intervenor to meet jurisdictional requirements. See, e.g., Durkin v. Pet Milk Co., 14 F.R.D. 374 (W.D. Ark. 1953) ; Tachna v. Insuranshares Corp., 25 Supp. 541 (D. Mass. 1938). Concerning the relationship of the right of intervention to the amount in controversy, sec 4 Moore, Federal Practice \ 24.18 (2d ed. 1950) (hercinafter cited as Moone). 
each plaintiff's expenses, and it might hasten recovery. But any such procedure is fraught with danger. A trial involving a maze of claims might well confuse a jury. Evidence admissible against one claimant, but not against another, might be considered by the jury in determining both claims. ${ }^{15}$ The claimant might get an award smaller than the one he would receive if the jury heard his claim separately. ${ }^{13}$ A consolidation procedure which utilizes representative suits poses additional problems. ${ }^{17}$ The few who litigate on belnalf of the many may be represented by counsel who will not prepare the best possible case. ${ }^{18}$ The suits may be collusive. ${ }^{19}$. And a non-litigating plaintiff may wish to rely on a legal theory or a set of facts which his representatives ignore but which might be successful.

It is difficult to force unwilling claimants to participate in a procedure for consolidation. In order to limit litigation by producing decisions binding on all claimants, a method of consolidation must operate within constitutional, statutory, and doctrinal confines. The major obstacles are three: jury trial, service of process, and jurisdiction.

The right to jury trial "in is important because historically some of the methods for dealing with multiple actions have required the aid of normally jury-less courts of equity. ${ }^{21}$ The right to trial by jury is a continuation of the right as it existed prior to the adoption of the federal and the various state constitutions. ${ }^{22}$ Consequently, in the absence of wairer, a present-day cuurt sitting without a jury may try only those cases which were trialle without a jury liefore the enactment of the constitutions, or which involve remedies or claims un-

15. See Chafee, Sodfe Probiems of Egum 152 (1950) (hercinufter cited 3s ChafeE).

16. See note 82 infra.

17. For a discussion of representative suits, see text at note $110 \mathrm{et} \mathrm{seq}$. infru.

18. See Horwood v. Statesman Pub. Co., 98 L.J.K.B. 450, 456 (1929). See also Chafee 227; note 187 infra.

19. See Wabash R.R. v. Adelbert College, 208 U.S. 38, is (1908). But see Kalven \& Rosenfield, The Contemporary Function of the Class Stit, 8 U. of CHI. L. REv. 68:, 713 (1941).

20. U.S. Coxst. Axrevd. VII. State constitutions also guarantee jury trial. See, e.g., Tillery v. Commercial Nat. Bank of Anniston, 241 Ala. 653, 655-6, 4 So.2d 125, 127 (1941).

21. E.g., First State Bank v. Chicago, R.I. \& P.R.R., 03 F.2d 585 (8th Cir. 1933) (bill to restrain a multitude of suits against the plaintiff). Juries have generally bacn unavailable in equity courts. E.g., Conrocode v. Ohio Bell Tel. Cu., 11 li.R.U. 3103 (N.L. Ohio 1951); Ford v. Palisades Corp., 101 Cal. App. 2d 491, 25 P.2d 545 (1950); Runyan v. Bangs, 167 Kan. 691, 208 P.2d 600 (1949).

Juries may be unavailable in equity even where law and equity have lieen maged. Sos Hasty v. Pierpont, 146 Kan. 517, 72 P.2d 69 (1937). This may depend, however, upon whether the action is equitable in nature. Bettencourt v. Bank of Italy, 216 Cal. 174, 13 P.2d 659 (1932).

22. E.g., Hoehamer v. Village of Elmwuod Park, 3tsl Ill. 422, 198 N.E. 345 (1935); People v. Kelly, 347 I1l. 221,179 N.E. SOS (1931); MeXlaster v. Wilkineon, 145 Xeh. 34, 15 N.W.2d 348 (1944); White v. White, 10S Tex. 570, 14t S.IF. 50X (1917); LaBuwe v. Balthazor, 180 Wis. 419,193 N.W. 24 (1923). 
like any known at that time. ${ }^{28}$ This fact does not in itself present insurmountable difficulties in finding methods of dealing with mass torts. ${ }^{24}$ But apart from constitutional considerations, American judicial policy has disfavored negligence trials by a court without jury. ${ }^{25}$ It seems unlikely that this tradition will be broken cavalierly for the sake of the defendant's convenience in mass tort litigation. ${ }^{20}$

23. Canses unknozen at time of constitutional adoption: Welchel v. McDonald, 340 U.S. 122 (1950), rehearing denied, 340 U.S. 923 (1951) (action against United States) : United States v. Sherwood, 312 U.S. 584 (1941) (same); Ryan Distributing Corp. v. Caley, 51 F. Supp. 377 (E.D. Pa. 1943) (action for declaratory judgment) ; McLachlan v. McLachlan, 101 Cal. App. 106, 281 Pac. 512 (1929) (divorce action); Breimhorst v. Beckman, 227 Minn. 409, 35 N.W.2d 719 (1949) (proceeding before administrative agency).

Causes triable without jury at time of constitutional adoption: In re England's Estate. 214 Cal. 298, 5 P.2d 428 (1931) (probate) ; Dettenborn v. Hartford-National Bank, 121 Conn. 388, 185 Atl. 82 (1936) (same). See also Moore, Federal Rules of Civil Procedure: Some Problems Raised by the Preliminary Draft, 25 Geo. L.J. 551 (1937); Notes, 56 Harv. L. Rev. 282 (1942) ; 13 So. Calif. L. Rev. 170 (1939). But cf. Dallas Joint Stock Land Bank v. State, 133 S.W.2d 827 (Tex. Civ. App. 1939) (independent suit in nature of a bill of discovery [a remedy which apparently was not known at time of adoption of state constitution] warrants jury trial) ; Tolle v. Tolle, 101 Tex. 33, 104 S.W. 1049 (1907) (in an action involving the granting of letters of administration, the court decided that-even though that cause was unknown at common law-the right to jury trial existed, since a probate proceeding was a "cause" within meaning of Art. $5 \$ 10$ of the Texas constitution). Also see Harris, Jury Trial in Civil Cascs-A Problcm in Constitutional Interpretation, 7 SOUTHWEsterN L.J. 1 (1953).

24. See text at note 100 et seq. infra.

The constitutional guarantee of the right to trial by jury does not necessarily preclude equity from assuming jurisdiction in order to avoid a multitude of actions at law. First State Bank v. Chicago, R.I. \& P.R.R., 63 F.2d 585 (8th Cir. 1933); Weininger v. Metropolitan Fire Ins. Co., 359 Ill. 584, 195 N.E. 420 (1935). But sed Murphy \& Sons, Inc. v. Peters, 95 N.H. 275, 276, 62 A.2d 718, 719 (1948).

25. "[T]here is a strong popular feeling in this country that negligence suits should be tried by a jury. This is based on the belief that judges would be more favorable than juries to the large corporations which are commonly defendants in such cases. Whether this belief is founded in fact or not, it can not be ignored, for it is important, not only that the people should get justice, but also that they should feel that they are getting justice." ChafeE 186-7 (1950).

In simple negligence cases, courts grant the right to jury trial. Bouis v. Aetua Casualty \& Surety Co., 98 F. Supp. 176 (W.D. La. 1951) (negligence action for faulty firearm); McGregor v. Wright, 117 Cal. App. 186, 3 P.2d 624 (1931) (malpractice action); Morgan v. Tennessee Cent. Ry., 31 Tenn. App. 409, 216 S.W.2d 32 (1948) (wrongful death); Leary v. Fisher, 248 Mich. 574, 227 N.W. 767 (1929) (negligence in operation of automobile) ; Lawrence v. Kansas Power \& Light Co., 167 Kan. 45, 204 P.2d 752 (1949) (same).

26. Where there is an assertion of doubtful equity jurisdiction, doubts are resolved by declaring the action to be at law. Pankey v. Ortiz, 26 N.M. 575, 195 Pac. 906 (1921); Likowski v. Catlett, 130 Okla. 71, 265 Pac. 117 (1928) ; accord. Peterson v. Sucro, 93 F.2d 878 (4th Cir. 1938).

Such is not the case, however, where monetary damages are merely incidental to requested equitable relief. NLRB v. Jones \& Laughlin Steel Corp., 301 U.S. 1 (1937); Jamaica Savings Bank v. M. S. Investing Co., 274 N.Y. 215, 8 N.E.2d 493 (1937). 
It is a policy which will certainly restrict any proffered solution, as it has restricted solutions in the past. ${ }^{27}$

The second obstacle is the right to service of process or "notice." Constitutionally, the decision in an in personam action, such as the usual tort suit, cannot bind a person who has not received personal service of process or its equivalent. ${ }^{28}$ Therefore, a mass tort claimant cannot be bound by the decision in a representative suit of which he has received no notice. ${ }^{3}$ By federal rule, personal service in most in personam actions is valid only in the state in which the district court sits." Some state courts have no power to issue pro-

27. See note 103 infra.

28. Pennoyer v. Neff, 95 U.S. 714 (1877).

29. See Keffee, Levy \& Donovan, Lee Defcats Bew Hur, 33 Casteul L.Q. 327, 344-50 (1948): Kalven \& Rosenfield, supra note 19, at 713; Conment, 46 Cum L. REv. 818 (1946).

Many representative actions involve a res to which several indisyensible garties are asserting claims. Then a conclusive decree may be given without affirding jroper notice to all interested parties. Supreme Tribe of Ben-Hur v. Cauble, 255 C.S. $35 \%$ (1921); Smith v. Swormstead, 16 How. $28 S$ (U.S. 1853) ; Mrontgomery v. Equitable Life Assurance Soc'y, 83 F.2d 758 (7th Cir. 1936) (persons not in being bound by a derreel; Luter v. Martin, 58 F.2d 537 (7th Cir.), cirt. dented, 237 U.S. 637 (1932) (eredit.r's bill1: Waybright v. Columbian Mutual Life Ins. Co., 30 F. Supp. 885 (W.D. Tenn. 1939); Southern Ornamental Iron Works v. Morrow, 101 S.W.2d 33t (Tex. Civ. Apl. 1937) (action against members of a reciprocal insurance company to recuver prumiumsl.

The great danger, however, in foregoing or relaxing service uf jrosest requircment, is that the supposed class may consist of members whone interests may cunflict an among themselves. See, c.g., Hansberry v. Lee, 311 U.S. 32 (1910). A partial answer to this problem is that the decree in many situations binds only those parties who assent th the litigation in their behalf. See note 136 infra. In addition, in a representative "Ir class, action, there is the requirement that there be adequate representation. It has lieen argued that it would be contradictory to say that there is adequate representation of a class within which there exist antagonistic or conflicting interests. Linden Land Co. Y. Mil= waukee Electric Ry. \& Light Co., 107 Wis. 493, 83 N.W. 851 (1900). Also see Kalven \& Rosenfield, supra note 19 at 711.

In certain instances, courts have made a decree binding on all members of the class if they are convinced that there has been proper notice-even though there has not becn the traditional service of process. Women's Catholic Order of Foresters v. City of Ennis, 116 F.2d 270 (5th Cir.), cort. dcnied, 313 U.S. 589 (1941); Towle v. Dunnell, 49 F 2149 (6th Cir. 1931) ; Phipps v. Chicago, R.I. \& P.R.R., 234 Fed. 945 (8th Cir.), cert. granted, 261 U.S. 611 ; writ of crror dismissed, 262 U.S. 762 (1923); Throckmurton v. Hiclman, 279 Fed. 196, 201-02 (3d Cir. 1922) ; Hefferman v. Liennet \& Armour, 110 Cal. Apl. 2d 564, 590, 243 P.2d 846, 862 (1939) ; American State Savings Bank, Trustce v. American State Savings Bank, 2ss Mich. 78, 2S4 N.W. 652 (1932). Professor Mre criticizes this practice, declaring that "such an 'analysis' seems, at most, to be relegating the entire doctrine to the haphazardous concept of 'fireside equity." Only confusion has renultcd in such a criterion." 3 Majke 3470 . For a contrary view, see Comment, th Cils. L. REY. \$18, $\$ 33$ n.68 (1946).

30. Federal Rule 4(f) provides that "all process other than a subpuena may be served anywhere within the territorial limits of the state in which the distriet court is held, and when a statute of the United States so provides, beyond the territorial limits of that state..." Fen. R CIv. P. f(f), Mississippi Pub. Corp. v. Mfurphree, 326 C'.S. 438 (1946). "Congress has undoubted power to authorize a suit under federal law to be brought in any United States district court, and to provide that process may run intu any part of the 
cess to someone in a county other than the one in which an in personam action is begun. ${ }^{31}$ And due process is not satisfied by service by publication-or other constructive service-issued to persons not resident in the jurisdiction. ${ }^{32}$ Constructive service is permissible only when it is the sole means by which to give residents notice of a suit to which they are necessary and proper parties. ${ }^{83}$ A legislature may in no case authorize a method of notification which in fact gives no notice at all. ${ }^{34}$ Furthermore, service by mail is impracticable in the mass tort situation, because many potential plaintiffs may be unknown. ${ }^{36}$ Early cases allowed one party to accept service for another if the parties were in "privity."36 But the mere fact that the parties have a common interest in a

United States, but it has not done so by general law." Howard v. United States, 120 F.2d 667, 668 (10th Cir.), cert. denied, 316 U.S. 699 (1942). See also 2 Moore if 4.29; 2 id. If 4.19 (discussion concerning service on an individual pursuant to statc law).

Those statutes which authorize service of process on a defendant in any district where defendant resides or transacts business have almost uniformly been interpreted as not applying to third party defendants. United States v. Rhoades, 14 F.R.D. 373 (D. Colo. 1953).

31. Valentine v. Franklin Surety Co., 11 N.J. Misc. 822, 168 Atl. 35 (1933); Deaton v. Evans, 192 Tenn. 348, 241 S.W.2d 423 (1951); Walden v. Locke, 33 S.W.2d 475 (Tex. Civ. App. 1930).

This is not the case if the action is in rem or if permission is granted by a constitutional or statutory provision. Williams v. Cooper, 222 N.C. 589,24 S.E.2d 484 (19-13) ; State $c \cdot x$ rel. Hawley v. Industrial Comm., 64 Ohio App. 271, 28 N.E.2d 654, all'd, 137 Ohio St. 332, 30 N.E.2d 332 (1940) ; Hall v. Ocean Accident \& Guarantee Corp., 122 W. Va. 188,9 S.E.2d 45 (1940).

32. Indemnity Ins. Co. of N.A. v. Smoot, 152 F.2d 667 (D.C. Cir. 1945); Bank of Edwardsville v. Raffaelle, 381 Ill. 486, 45 N.E.2d 651 (1942); Southern Mills v. Arm= strong, 223 N.C. 495, 27 S.E.2d 281 (1943); Sheehan v. Mathews, 258 Wis. 006, 46 N.W.2d 752 (1951).

Quasi in rem jurisdiction may be established, however, if the non-resident defendant has property in the state. Southern Mills v. Armstrong, supra; Indemnity Ins. Co. of N.A. v. Smoot, supra.

33. Bray v. Germain Inv. Co., 105 Colo. 403, 98 P.2d 993 (1940); Dixie Meadows Independence Mines Co. v. Kight, 150 Ore. 395, 45 P.2d 909 (1935); In re Bergman's Survivorship, 60 Wyo. 355, 151 P.2d 360 (1944). Statutes which provide for constructive service must be complied with strictly. Southern Mills v. Armstrong, 223 N.C. 495, 27 S.E.2đ 281 (1943) ; Erickson v. Macy, 231 N.Y. 86, 131 N.E. 744 (1921). For service by publication to be binding on unknown persons, in those situations in which such service is permitted, every effort must be made to ascertain the names and addresses of unknown parties. Callner v. Greenberg, 376 Ill. 212, 33 N.E.2d 437 (1941).

34. Mullane v. Central Hanover Bank \& Trust Co., 339 U.S. 306 (1950); Wuchter v. Pizzuti, 276 U.S. 13, 24 (1928) ; Horvath v. Brettschneider, 131 Misc. 618, 227 N.Y. Supp. 109 (City Ct. 1928).

See generally Eulette, Service of Process Upon Foreign Corporations-Constilutional Limitations Imposed by Judicial Construction of the Due Process Clanse, 20 CHI-KeNT L. Rev. 287 (1942) ; Notes, 39 Y AlE L.J. 126 (1929); 25 N.Y.U.L.Q. Rev. 896 (1950); 12 So. CaLIF. L. REv. 464 (1939).

35. Even if the parties were known, such service would not be valid as against nonresidents. Doctor's Hospital v. Kahal, 155 Misc. 126, 277 N.Y. Supp. 736 (City Ct.), aff'd' - App. Div.

36. See text at note 61 infra. 
question of law or fact does not establish such "privity."3i Hence, the doctrine affords little help in mass tort litigation. ${ }^{38}$ Since mass torts characteristically involve claimants residing in several jurisdictions, service of process in a troublesome requirement.

The final obstacle to consolidation of mass tort litigation is jurisdictional. Federal courts have limited jurisdiction $3^{30}$ the Constitution linits the controversies they may hear. ${ }^{40}$ And "at no time has Congress granted to the Federal Courts the full measure of power which it was authorized to grant by . Irticle III of the Constitution." $\neq 1$ Moreover, Congress has provided 42 that a federal court may not issue an injunction to stay a concurrent state proceeding except where authorized by statute, ${ }^{\mathbf{3}}$ or where restraint is necessary to preserve its jurisdiction ${ }^{24}$ or to protect or effectuate its judgment. ${ }^{45}$ Either a state or

37. Holt Mff. Co. v. Collins, 154 Cal. 255, 97 Pac. 516 (1908).

At common law, a voluntary unincorporated group or association could not be sued in its common name. Absent an enabling statute, individual process had to be served on the members. Johnston v. Albritton, 101 Fla. 12\$5, 134 So. 563 (1931). See also 94 A.L.R. 854 (1935). For an example of an enahling statute, see J. Earl Jardine v. Superior Court, 213 Cal. 301, 303-5, 2 P.2d 756, 757-S (1931).

38. There may, however, be "privity" in the mass turt situation, where the action concerns a common fund to which a class of claimants have joint and inseverable rights. See text at note 86 infra.

39. See, e.g., Shulman \& Jaegerman, Some Jurisdictional Limilatims on Federal Procedure, 45 Yale L.J. 393 (1936).

40. See U.S. Covsr. ART. III. The following are situations in which Cungress has given the federal courts exclusive jurisdiction: Grand River Dam Authority y. Parker, 40 F. Supp. \&2 (N.D. Okla. 1941) (cmincnt domain) ; Bowles v. Willinglam, 321 U.S. 503 (1944) (Emergency Price Contral Act except \$ 205); Hawkins v. Merrill, Lyneh. Pieres. Fenner \& Beane, 85 F. Supp. 104 (W.D. Ark. 1949) (Securities and Lexchange 1eth): Vii. liamson v. Columbia Gas \& Electric Corp., 27 F. Supp. 198 (D. DeL. 1439) (antitrust); Cavicchi v. Mohawk Mffg. Co., 34 F. Supp. 852 (S.D.X.Y. 1946) (patent infringement).

Federal courts have concurrent jurisdiction with state courts in diversity cases, 28 U.S.C. $\$ 1332$ (Supp. 1952), or if so provided by a congressional statute. Werbe v. Holt, 98 F. Supp. 614, 617 (W.D. Ark. 1951); Hargrave v. Mrid-Continent Pet. Corp., 36 F. Supp. 233 (E.D. Okla. 1941) (Fair Labor Standards Act).

In personam actions may run concurrently. Princess Lida of Thurn and Taxis v. Thompson, 305 U.S. 456 (1939) ; Pennsylvania Gen. Cas. Co. v. Pennsylvanis, 294 U.S. 189 (1935); Kline v. Burke Construction Co., 260 U.S. 226 (1922); Rankin v. Iron City Sand \& Gravel Corp., 356 Pa. 548, 52 A.2d 455 (1947).

41. Shulman \& Jaegerman, supra note 39 , at 394-5.

42. 62 Stat. 968 (1948), $2 S$ U.S.C. $\$ 2283$ (Supp. 1952).

43. This power can be utilized where the federal courts have exclusive jurisdiction. See note 40 supra. See also Moore's Comarentary on the United States Judictal Cone 410 (1949).

44. See Kline v. Burke Construction Co., 250 U.S. 226 (1922); Toucey v. New York Life Ins. Co., 314 U.S. 118, $134-7$ (1941). The most common cases of this type are the so-called "res" cases. See Mandeville v. Canterbury, 318 U.S. 47 (1943) ; Bryant v. Atlantic Coast Line R.R., 92 F.2d 569 (2d Cir. 1937); Jennings \& Co. v. Buterbaugh, 89 F. Supp. 553 (W.D. Pa. 1950). See also Warren, Federal ard State Court Interferestec, 43 HARv. L. REv. 345, 359-66 (1930). For additional information on the seope of this exception, see Moore, op. cit. supra note 43, at 411-14.

45. See Jackson v. Carter Oil Co., 179 F.2d 524 (10th Cir.), cert. denied, 340 U.S. 
federal court may stay a proceeding before it, pending determination of the same issues in another court. ${ }^{46}$ And a state court can restrain parties over which it has jurisdiction from prosecuting actions in another state. ${ }^{47}$ But the jurisdiction of state courts is limited by the fact that they may not interfere with foreign in personam actions by issuing an order or decree directed to a court in another state. ${ }^{48}$ In sum. no court, state or federal, can enjoin a tort action in a jurisdiction other than its own, unless the action has been brought under the Federal Tort Claims Act. ${ }^{49}$ This principle of limited juriscliction is important in multiplicity situations since tort actions, transitory in nature, may be instituted against a defendant in any juriscliction in which he can be found. ${ }^{50}$ And the fact that a claimant can sue a corporation in any state in

812 (1950): Maryland Casualty Co. v. Glassell-Taylor \& Robinson, 68 F. Supp. 897 (W.D. La. 1946).

46. Generally, a federal court will stay proceedings out of comity, where trial has already begun in state court, where a decision has been reached and is being appealed, or where state court jurisdiction is in issue. Township of Hillsborough v. Cromwell, 326 U.S. 620, 677 et seq. (1946) ; Klanian v. New York Life Ins. Co., 39 F. Supp. 777 (D.R.I. 1941).

Federal courts will not, however, stay an in personam action just because of a pending action in state court; if the jurisdictional requirements are met, a plaintiff is considered to have an absolute right to proceed in the federal courts. See Township of Hillsborough v. Cromwell, supra; Great North Woods Club v. Raymond, 54 F.2d 1017 (6th Cir. 1931).

For examples of state conflict problems, see Ormsby v. Chase, 290 U.S. 387, 389 (1933); White v. Central Dispensing \& Emergency Hospital, 99 F.2d 355, 362 (D.C. Cir. 1938) ; Loranger v. Nadeau, 215 Cal. 362, 10 P.2d 63 (1932). In such instances, courts generally require that the suits involve the same parties, and the same subject matter. Simmons v. Superior Court, 96 Cal. App. 2d 119, 214 P.2d 844 (1950); Evans v. Evans, 186 S.W.2d 277, 279 (Tex. Civ. App. 1945).

47. The injunction will generally be honored in the second state on grounds of comity. Hall v. Milligan. 221 Ala. 233, 128 So. 438, 440 (1930); New Orleans \& N.E.R.R. v. Bernich, 178 La. 153, 150 So. 860 (1933). Contra: Pitcairn v. Drummond, 216 Ind. 54, 56, 23 N.E.2d 21, 22 (1939) ; Boston \& M.R.R. v. Whitehead, 307 Mass. 106, 108, 29 N.E.2d 916, 917 (1940); Evans v. Morrow, 234 N.C. 600, 604, 68 S.E.2d 258, 261 (1951). The "full faith and credit" clause does not require that the injunction be honored. Standard Oil Co. v. Reddick, 202 Ark. 393, 395-6, 150 S.W.2d 612, 614 (1941); Sullivan v. McFetridge, — Misc. ——, 55 N.Y.S.2d 511 (Supp. Ct. 1945).

48. Husband v. Crockett, 195 Ark. 1031, 115 S.W.2d 882 (1938) ; Morad v. Williams, 177 Misc. 933, 32 N.Y.S.2d 463 (Sup. Ct. 1942) ; New York, C. \& St. L.R.R. v. Matzinger, 136 Ohio St. 271,25 N.E.2d 349 (1940). See also Miles v. Illinois Central R.R., 315 U.S. 698, rehearing denied, 316 U.S. 708 (1942) (action under Federal Employers' Liability Act).

Instituting a proceeding in one county is not a bar to an action in another county of the same state, but the second court may refuse jurisdiction on grounds of comity. Pcaslec v. Miller, 119 Misc. 452, 193 N.Y. Supp. 134 (Sup. Ct. 1923). But cf. Sult v. Gilbert, 148 Fla. 421, 4 So.2d 463 (1941); In re Hange's Estate, 219 Minn. 192, 17 N.W.2d 305 (1945) ; Petition of Herl, 230 Wis. 312, 284 N.W. 42 (1938).

49. 60 STAт. 812 (1946), 28 U.S.C. $\$ 1346$ (1946). This act grants exclusive jurisdiction to the federal district courts; see note 127 infra.

50. Draper v. Louisville \& N.R.R., 348 Mo. 886, 156 S.W.2d 626 (1941) ; Southern Pacific Co. v. Allen, 48 Tex. Civ. App. 66, 106 S.W. 441. (1907). But cf. Mowat v. United Fruit Co., 37 N.Y.S.2d 93 (Sup. Ct. 1942). 
which it does business ${ }^{51}$ practically guarantees that claims resulting from a mass tort will crop up in several forums.

The defendant's desire to restrict litigation, the claimant's interest in procuring an individual hearing. and the legal obstacles to consolidation must all be considered in an analysis of the procedural devices presently arailable fiur limiting litigation resulting from a mass tort. These devices-the class action, consolidation of actions, the bill of peace, and in exceptional cases receivership proceedings-were formulated more with an ere toward contract litigation. Although infrequently used in the tort field, the procedures have shown the most promise where injunctive relief is sought. ${ }^{53}$ Nevertheless, there is a history of legal principles for applying such methods to damage claims arising out of mass torts..$^{\text {i4 }}$

\section{The Equitable Bill of Peace}

Early English courts of law developed a method for dealing with a multiplicity of suits arising out of the same fact situation. In utilizing this device. known as quasi-consolidation, a law court would stay actions pending against a defendant -or actions by a single plaintiff against a group of defendants. ${ }^{5 \pi}$ Then the court would try all common questions of law and fact in a single suit. 56 But the effectiveness of quasi-consolidation was limited. The decision in the single suit bound only those who agreed to be bound. ${ }^{57}$. And a common law judge, lacking injunctive powers, could stay only those actions pending in his own court. ${ }^{3 \mathrm{~s}}$

51. Davis v. Farmers' Co-op Equity Co., 262 U.S. 312 (1923).

The doctrine of forum non conz'ssicns may deny plaintiffs access to some fors. Gulf Oil Corp. v. Gilbert, 330 U.S. 501 (1947). See also Goonach. Conflicts ur Laws 22-4, 42 (3d ed. 1949).

52. In non-tort litigation, there is more apt to be a res, privity among multiple parties, or the assertion of joint rights. Cases involving such factors lend themselves readily to a single determination, without evoking the charge that each person ought to have the right to litigate his case separately. Cf. text at note $77 \mathrm{infro.}$

53. See text at notes 151 et seq. infra.

54. ChafeE C. 5.

55. See Mutual Life Ins. Co. v, Hillman, 145 U.S. 285, 292-3 (1892). This would occur only if the multiple parties were joint obligees or obligors, since these were the only actions a court of law would join. In England this is nu longer the case. Sce 26 H.ussucry" LAws of ENGLANo (2d ed. 1951), $\$ 94$ of which provides that actions may now be consolidated where they relate to the same subject matter (1) between the same plaintifi and defendants, (2) between different plaintiffs and the same defendants, (3) between the same plaintiffs and different defendants, and, (4) between different plaintiffs and defendants, upon the application of any party. For the present day meaning of the term "quasi-consolidation" see note 13 supra.

56. See Chafee 153-4.

57. Id. at 154. MY'Gregor v. Horsfall, 3 MI. \& W. 320 (1838) ; Hodson v. Richardson, 3 Burr. 1477 (1764); see also Journeymen Taylors in Edinburgh v. The Incorporation of Taylors, 9 Morrison's Dec. 7364 (1770).

58. See note 46 supra. 
To provide a more adequate means of confining litigation of multiple claims, English equity devised the bill of peace. ${ }^{59}$ Through this procedure, as in quasi-consolidation, one of the multitude sued or was sued on behalf of the multitude. ${ }^{60}$ But in addition, the court of equity boasted features which law could not provide. By entertaining a bill of peace, it could enjoin the parties before it from bringing separate actions in any court, not just its own. ${ }^{\text {"1 }}$ Whether or not they consented, all members of the multitude were bound by the equity court's decision. ${ }^{62} \mathrm{~A}$ chancellor, sitting as trier of fact, was better qualified than a jury to avoid prejudice by considering evidence only when determining the rights of those parties against whom it was admissible. ${ }^{63}$ And equity could afford relief no less exhaustive than that available at law. ${ }^{64}$ Once its jurisdiction was established, the court could grant not only equitable relief but also any legal redress necessary to effectuate complete equity among all the interested parties. ${ }^{65}$

But equity cannot entertain a bill of peace unless grounds for equity jurisdiction exist. ${ }^{66}$ In some instances, the separate actions are originally brought in

59. Merrill v. Lake, 16 Ohio 373, 47 Am. Dec. 377 (1847). See also 1 Poneroy, Equity Jurisprudence $\$ 246$ (4th ed. 1918) ; Chafee 157-9.

60. For examples of cases involving multiple plaintiffs, see Liverpool \& London \& Globe Ins. Co. v. Clunie, 88 Fed. 160 (C.C.N.D. Cal. 1898); Ehrlich v. Teague, 209 Ga. 164, 71 S.E.2d 232 (1952); Sheffield Waterworks v. Yeomans, L.R. 2 Ch. 8 (1866). See also National Organization, United Mine Workers of America v. Red Jacket Consol. Coal \& Coke Co., 18 F.2d 839 (4th Cir. 1927); Conyers v. Lord Abergavenny, 1 Atk. *285 (1738).

For examples of cases involving multiple defendants, see Burdick v. Snyder, 69 F. Supp. 280 (D.D.C. 1946) ; National Hairdressers' \& Cosmetologists' Ass'n v. Philad Co., 41 F. Supp. 701 (D. Del. 1941), aff'd, 129 F.2d 1020 (3d Cir. 1942) ; Fidelity Union Trust Co. v. Cochrane, 116 N.J. Eq. 190, 172 Atl. 800 (Ch. 1934); Mayor of York v. Pilkington, 1 Atk. *282 (1737); Cowper v. Clerk, 3 P. Wms. 155 (1732).

61. This injunction barred actions both at law and in equity. Erie Ry. v. Ramsey, 45 N.Y. 637, 653 (1871) ; Smith v. St. Louis Mut. Life Ins. Co., 6 Lea 564 (Tenn. 1880). See also Cowper v. Clerk, 3 P. Wms. 155 (1732); Fitton v. Macclesfield, 1 Vern. *287 (1684).

62. Sheffield Waterworks v. Yeománs, L.R. 2 Ch. 8 (1866). Also see cases cited notes 60-1 supra.

63. See Chafee 155-6, 186-9.

64. See Natural Gas Pipeline Co. v. FPC, 128 F.2d 481 (7th Cir. 1942); Burdick v. Snyder, 69 F. Supp. 280 (D.D.C. 1946).

65. But it was always necessary for an action to involve some matter over which equity traditionally had jurisdiction before it would grant legal relicf. Ind, Coope \& Co. v. Emmerson, 56 L.J. Ch. 989 (1887); Ware v. Horwood, 14 Ves. $* 27,33$ (1807); How v. Tenants of Bromsgrove, 23 Eng. Rep. 277, 1 Vern. *22 (1681); Natural Gas Pipe Line Co. v. FPC, 128 F.2d 481 (7th Cir. 1.942); Ehrlich v. Teague, 209 Ga. 164, 71 S.E.2d 232 (1952) ; Fidelity Union Trust Co. v. Cochrane, 116 N.J. Eq. 190, 172 Atl. 800 (Ch. 1934).

66. Mayor of York v. Pilkington, 1 Atk. *282 (1737); Smith v. Bivens, 56 Fed. 352 (C.C.D.S.C. 1893) ; Boston \& M.R.R. v. Sullivan, 177 Mass. 230, 58 N.E. 689 (1900); Smith v. Smith, 148 Mass. 1, 18 N.E. 595 (1888) ; Fidelity Union Trust Co. v. Cochranc, 116 N.J. Eq. 190, 172 Atl. 800 (Ch. 1934); Warren v. Parkhurst, 186 N.Y. 45, 78 N.E. 579 (1906). 
equity. Then, since the court has had jurisdiction from the beginning, it can issue the bill of peace without finding further grounds for equitable intervention. ${ }^{67}$ But in the mass tort situation-and many others-all of the separate suits begin as pure actions at law for damages. Before it will wrest the litigation away from law, equity must be shown a reason for granting equitable relief. ${ }^{03}$ And in such a situation, equitable intervention is permissible, not mandatory. ${ }^{63}$

Early English cases held that the mere fact of multiplicity was sufficient to render legal redress inadequate ${ }^{\mathrm{TC}}$ and to create a right to equitable intervention through the bill of peace. ${ }^{i 1}$ Some shaky American precedent agrees. ${ }^{72}$ But for centuries the preponderence of English ${ }^{73}$ and American authority ${ }^{74}$

67. Chafee 167-70.

68. See cases cited note 66 supra.

69. Hamrick v. Hamrick, $206 \mathrm{Ga} .564,567-8$, 58 S.E.2d 145, 148 (1950); Hanson v. Gardiner, 7 Ves. 306 (1802).

70. Corporation of Carlisle v. Wilson, 33 Eng. Rep. 297, 298, 13 Ves. 276, 279 (1807); Poor v. Clarke, $2 \mathrm{Atk}$ *515 (1742) (law inadequate, since in order finally to adjudieate a question all necessary parties must be before the court). Ware v. Horwood, 14 Ves. *27, 34-5 (1807). But cf. Ryves v. Wellington, 9 Beav. 579 (1846) (mere absence of remedy for supposed wrong in another court is not sufficient reason for equity to assume jurisdiction).

71. Sheffield Waterworks v. Yeomans, L.R. 2 Ch. App. $S$ (1866); Pawlet v. Ingres, 23 Eng. Rep. 487, 1 Vern. *308 (1863) : Ware v. Horwood, 14 Ves. *27 (1807); Cowper v. Clerk, 3 P. Wms. 157 (1732); Lord Tenham v. Herbert, 2 Ath 484 (1742). See also discussion in Chafee 162-3. Compare How v. Tenants of Brumsgrove, 23 Eng. Rcp. 2y7, 1 Vern. $" 22$ (1681) ; Conyers v. Lord Abergavenny, 1 Atk. $\approx 285$ (1738), civilh cases stsfru.

72. First State Bank v. Chicago, R.I. \& P.R.R, 63 F.2d 585 (8th Cir. 1933); Fish v. Kennamer, 37 F.2d 243 (10th Cir. 1929) ; Munson Inland Lines, Ine v. Ins. Co. of North America, 36 F.2d 269 (S.D.N.Y. 1929) ; Warren Bros. Co. v. Kibbe, 43 F.2d 5\&2 (D. Ore. 1925) ; Southern Steel Co. v. Hophins, 157 Ala. 175, 47 So. 274 (1908); Whitlock v. Yazoo \& M. Valley R.R., 91 Miss. 779, 45 So. 861 (1908). But ef. Reanoke Guano Co. v. Saunders, 173 Ala. 347, 56 So. 198 (1911) ; Cumberland Tel. \& Tel. Co. v. Williamson, 101 Míiss. 1, 57 So. 559 (1912).

73. Ewelne Hospital v. Andover, 23 Eng. Rep. 460, 1 Vern. $\star 266$ (16S4) (requestcd relief vas more legal in nature than equitable); How v. Tenants of Bromsgruse, 23 Eng. Rep. 277, 1 Vern. "22 (1681) (privity required); Dilly v. Doig, 2 Ves. 486 (1794). See also Ylayor of York v. Pilkington, 1 Atk. $\approx 2 \$ 2$ (1737) (genersl right required).

74. Common interest: Georgia Power Co. v. Hudson, 49 F.2d 65 (4th Cir. 1931); Watson v. Huntington, 215 Fed. 472 (2d Cir. 1914) ; National Hairdressers' \& Cosmetologists' Ass'n v. Philad Co., 41 F. Supp. 701 (D. Del. 1941), aff'd, 129 F.2d 1020 (3d Cir. 1942); Turner v. Mobile, 135 Ala. 73, 33 So. 132 (1902); Morgan v. Mforgan, 3 Stew. 383, 21 Am. Dec. 638 (Ala. 1831); Vandalia Coal Co. v. Lawson, 43 Ind. App. 226, 87 N.E. 47 (1909); Stodder v. Rosen Talking Miachine Co., 241 Mass. 245, 135 N.E. 281 (1922) ; Tisdale v. Ins. Co. of North America, 84 Miss. 709, 36 So. 565 (1904); Tribette v. Illinois Cent. R.R., 70 Miss. 182, 12 So. 32 (1S92); Ducktown Sulphur, Copper \& I. Co. v. Fain, 109 Tenn. 56, 70 S.W. $\$ 13$ (1902).

Independent grounds of equitable jurisdiction: First State Bank v. Chicago, R.I. \& P.R.R., 63 F.2d 585, $5 \& 8$ (8th Cir. 1933) ; Ehrlich v. Teague, 209 Ga. 164, 17 S.E.2d 232 (1952).

Equity has been more willing to assume jurisdiction when a failure to do so weuld necessitate multiple suits between the same two parties. Steggles v. National Diseount 
has required more. Courts have been anxious to restrict equity jurisdiction. ${ }^{70}$ If the mass litigation is unduly complex, equity courts will refuse jurisdiction. calling the action multifarious. ${ }^{73}$ And they have deemed it unfair to require a litigant to have contested in a single complex suit a right which is personal to him alone. ${ }^{77}$ As a result, there has developed the now-established doctrine that a bill of peace will be entertained only when muttiplicity exists and when a "common interest" or "general interest" binds the multiple parties together. ${ }^{78}$

Like many general phrases. "community of interest" affords little predictability. ${ }^{79}$ Even recourse to history shows only that courts have garbled the term into an amorphous legal protoplasm. For purposes of analysis, the variant interpretations can be lumped into two categories : "rigid" definitions and "liberal" ones.

Proving a community of interest under a rigid rule requires a two-fold showing. First, the legal right asserted by each one of the multiple parties against the single party must share a common feature with the rights similarly asserted by the other multiple parties. ${ }^{80}$ Secondly, that common element must

Corp., 326 Mich. 44, 39 N.W.2d 237 (1949) ; Multiplex Concrete Machinery Co. v. Saxer, 310 Mich. 243, 17 N.W.2d 169 (1945).

75. In Scottish Union, etc. Ins. Co. of Edinburgh v. J. H. Mohlman Co., 73 Fed. 66, 67 (C.C.S.D.N.Y. 1896), the court, in an action by a plaintiff against many different insurers, remarked that "[I] t's contended that the numerous authorities cited in the bricf warrant the granting of such relief. In the opinion of this Court, however, none of them go to that length; and if the drift of some be in that direction, it would be a good time to call a halt. ..." See also Parkway, Inc. v. United States Fire Ins. Co., 314 Mass. 647, 650, 51 N.E.2d 436, 438 (1943).

76. Multifariousness has been found in a suit in equity based on separate claims against different persons where there is no common right to be established. Burger Lumber Co. v. Kirksey, 203 Ga. 439, 47 S.E.2d 68 (1948). In effect, multifariousness is another name for misjoinder of causes of action. See Van Antwerp v. Van Antwerp, 242 Ala. 92, 97, 5 So.2d 73, 77 (1941) ; Stamey v. Fortner, 230 Ala. 204, 205, 160 So. 116, 117 (1935); Essen v. Adams, 342 Mo. 1196, 1202, 119 S.W.2d 773, 777 (1938). See also Schell v. Leander Clark College, 2 F.2d 17, 21 (8th Cir. 1924): "The vice of multifariousness is the union of causes of action which, or of parties whose claims, it is either impractical or inconvenient to adjudicate in a single suit."

A bill, however, is not multifarious merely because all of the defendants are not interested in all the matters contained in a suit. Hastings v. H. M. Byllesby \& Co., 27 Del. Ch. 136, 32 A.2d 490 (Ch. 1943) ; Hyde v. Atlanta Woolen Mills Corp., 204 Ga. 450, 50 S.E.2d 52 (1948).

77. Chafee $152-3,155$.

78. These two phrases have been used interchangeably although there is some indication that, in their incipiency, their intended connotations were dissimilar. See Newton v. Egmont, 5 Sim. 130 (1832); Mayor of York v. Pilkington, 1. Atk. *282 (1737). Sec notes 73,74 supra.

79. For a general criticism, see 3 Moore 3417-8; Wheaton, Representative Suits Inzolving Numerous Litigants, 19 CoRNecL L.Q. 399, 407, 433 (1934); Blume, Thc "Common Questions" Principle in the Code Provision for Representative Suits, 30 Micu. L. REv. 878 (1932).

80. 1 Poxierox, op. cit. supra note 59, at 434. 
create a positive legal relationship-or "privity"-among the members of the multitude.81 The court must find that, apart from the effect of stare decisis, a decision separately disposing of one claim would determine the validity of all others. ${ }^{82}$ In essence, it is necessary to find that all of the multiple litigants would be indispensable or necessary parties to any action brought by any one of them. ${ }^{83}$ If one of the multitude succeeds, all the others would achieve their objective without further litigation. ${ }^{\$ 4}$ Under a rigid definition, "community" of interest" will be found in practice only when a common property right, ${ }^{65}$ franchise, or a common fund or trust fund underlies all of the multiple claims. ${ }^{86}$ Seldom can danage actions springing from a mass tort satisfy such stringent

81. Scott v. Donald, 165 U.S. 107, 115-16 (1897), quuting with approval Cutting v. Gilbert, 5 Blatchf. 259, 261 (S.D.N.Y. 1\&65).

S2. E.g., Gibbs v. Buck, 307 U.S. 66 (1939); Supreme Tribe of Ben-Hur v. Cauble, 255 U.S. 356 (1921) ; Montgomery Ward v. Langer, 168 F.2d $1 \$ 2$ (Sth Cir. 194\$).

In any case, of course, a prior decision dealing with roughly the same facts and legal issues may be apt to discourage future litigation, but this generally will not hold where recovery depends largely on factual issues which in turn depend on a multitude of intangibles which affect the jury. Compare Waters-Pierce Oil Co. v. Van Elderen, 84 Arl:. 555, 106 S.W. 947 (1907), with Waters-Pierce Oil Co. v. Knisel, 79 Arl 608, 96 S.W. 342 (1906). See also communication to the Yale Law Jouraral from Mir. R. N. Gilmore, Jr., Assistant Counsel of Association of Casualty and Surety Companies, dated Xiviember 16, 1953, in Yale Law Library: "I recall one airplane accident . . . in [which] Earl Carroll, the famous producer, was killed. The estate of Mr. Carroll, whose annual income at that time was estimated in excess of $\$ 1,000,000$ recovered nothing. The estates of others killed in the same crash recovered as much as \$200,000. If the question of negligence had been controlled by the Carroll case they would have recovered nothing."

83. E.g., Stodder v. Rosen Talking Mach. Co., 241 Mass. 245, 135 N.E. 251 (1922) (one of the parties suffered no damage, but the court held that the issuance of the injunction was not affected by his presence or absence); of. Zimmerman v. Finliclstein, 230 Mass. 17, 119 N.E. 194 (1918).

84. E.g., Dilly v. Doig, 30 Eng. Rep. 738, 2 Ves. 4866 (1794); Georgis Power Co. v. Hudson, 49 F.2d 66 (4th Cir. 1931); Watson v. Huntington, 215 Fed. 472 (2d Cir. 1914); Roanoke Guano Co. v. Saunders, 173 Ala. 347, 56 So. 198 (1911); Turner v. Mobile, 135 Ala. 73, 33 So. 132 (1902); Tribette v. Illinois Cent. R.R, 70 Afiss. 182, 12 So. 32 (1892).

85. E.g., Consumers Public Power Dist. v. Eldred, 146 Neb. 926, 936, 22 N.W.2d 189, 194 (1946). McCollum v. Smith, 233 N.C. 10, 15-16, 62 S.E.2d 483, 487 (1950); Kirby Lumber Corp. v. Southern Lumber Co., 192 S.W.2d 460, 463 (Tex. Civ. App.), aff'd, 145 Tex. 151, 196 S.W.2d 387 (1946).

See also Weeks v. Staker, 23 Eng. Rep. 794, 2 Vern. *301 (1693); Arthington v. Fawkes, 23 Eng. Rep. S24, 2 Vern. $* 356$ (1697) ; How v. Tenants of Bromsgrove, 23 Eng. Rep. 277,1 Vern. $* 22$ (1681), discussed in ChafEe 161 . These early actions were in the nature of a bill to quiet title, an action which has since become a traditionally equitable action. See 1 Poureroy, op. cit. stspra note 59, § 248.

86. Troy Bank v. G. A. Whitehead \& Co., 222 U.S. 39 (1911); Handley v. Stutz, 137 U.S. 366 (1890) ; Shields v. Thomas, 17 How. 2 (U.S. 1854); Natural Gas Pipeline Co. v. FPC, $12 S$ F.2d 481 (7th Cir. 1942); International Shoe Co. v. Pieard \& Geismer, Ltd., 30 F. Supp. 570, 577 (E.D. La. 1939), aff'd sub som. Mfayer v. Gros, 116 F.2d 733 (5th Cir. 1940). 
criteria. $^{87}$ Plaintiffs will generally assert claims involving a common legal question-the defendant's negligence, for instance. But "privity" seldom exists among such tort claimants. Hence, use of a rigid definition prevents most mass tort defendants from utilizing the bill of peace.

To alleviate the restrictiveness of a rigid definition, some American courts have shunned it in favor of a broad construction. Under this "liberal" interpretation, community exists where (1) the claims in clispute between the multiple parties and the single party have a common origin, and (2) all the disputes depend upon "common questions" of law and fact. ${ }^{88}$ Although this test insists that the legal relationships between the single party and his multiple opponents share a common legal element, it does not demand that the multiple parties stand in "privity" to each other ${ }^{80}$ By thus defining "community of interest," courts have entertained the bill of peace in mass tort litigation. ${ }^{90}$

3oth rigid and liberal interpretations of "community of interest" can lead to confusion. Many cases arise in which claimants have a common interest in some issues, but not in others. Literal reading of a rigid interpretation would lead to refusal of the bill of peace in such situations, on the ground that "privity" does not exist among the claimants on all questions presented for decision. ${ }^{91}$ In this way, use of the rigid view may deny the bill of peace in situations where it could be useful and where a tempered kind of "privity" does exist.

On the other hand, loosely interpreting the liberal view of common interest may allow the bill of peace to bind multiple parties to an entire decision, despite the fact that the decision was based on some common and some diverse questions of law and fact. For instance, if multiple plaintiffs suing for pollution of a stream are enjoined by a bill of peace and made to abide by one decision," either of two things could happen. The court might deny recovery bectuse

87. See note 91 infra.

88. United Mine Workers of America v. Red Jacket Consol. Coal \& Coke Co., 18 F.2d 839 (4th Cir. 1927) ; Pacific Fire Ins. Co. v. Anderson Co. of Nampa, 42 F. Supp. 917 (D. Idaho 1942); Liverpool \& London \& Globe Ins. Co. v. Clunie, 88 Fed. 160, (C.C.N.D. Cal. 1898).

89. Rodman v. Rogers, 109 F.2d 520 (6th Cir. 1940) ; Spear v. H. V. Greene Co., 246 Mass. 259, 140 N.E. 795 (1923); Kelly v. Tiner, 91 S.C. 41, 74 S.E. 30 (1912); Lindein Land Co. v. Milwaukee Electric Ry. \& Light Co., 107 Wis. 493, 83 N.W. 851 (1900). But cf. Certia v. University of Notre Dame, 82 Ind. App. 542, 141 N.E. 318 (1923) ; Garfein v. Stiglitz, $260 \mathrm{Ky} .430,86$ S.W.2d 155 (1935) ; Brenner v. Title Gtarantee \& Trust Co., 276 N.Y. 230, 11 N.E.2d 890 (1937).

90. Montgomery Light \& Water Power Co. v. Charles, 258 Fed. 723 (D. Ala. 1919); Hamilton v. Alabama Power Co., 195 Ala. 438, 70 So. 737 (1915); Smith v. Smith, 148 Mass. 1, 18 N.E. 595 (1888).

91. South East Nat. Bank v. Board of Education, 298 Ill. App. 92, 18 N.E.2d 584 (1938) ; cf. Weberpals v. Jenny, 300 IIl. 145, 133 N.E. 62 (1921).

92. See Rodman v. Rogers, 109 F.2d 520 (6th Cir. 1940) ; Greer v. Smith, 155 App. Div. 420, 140 N.Y. Supp. 43 (2d Dep't 1913). 
the defendant did not proximately cause the pollution. In that event, the bill of peace is justified, because the decision depended on the resolution of an issue which was common to all claimants. ${ }^{93}$ But the court might deny recovery to the representative plaintiff solely because he has shown no injury: If it then allows the bill of peace to stand, the court denies other claimants the chance to recover by binding them to the decision-despite the fact that they might well be able to show injury. The result is to deny claimants any right to relief.

The foregoing analysis suggests that courts should entertain the bill of peace readily, but limit its binding effect to questions which are in fact common to all claimants. The test should be whether determination of an individual issue in one suit will forestall re-litigation of that issue. ${ }^{04}$ But after the common issues have been resolved, each claimant should be left free to litigate additional questions-damages, for instance-which are peculiar to him alone. Since. under bill of peace procedure, the judge sits as trier of fact, he could sort out the legal issues and specify in his decision which issues he has determined, and which issues are not common and hence open to further contest. 05

Analysis also suggests the advisability in some situations of trying more than one representative suit under the bill of peace procedure. Suppose, for instance, that employees and passengers sue a railroad for injuries resulting from a negligent operation. All the employees have a common interest in the issue of contributory negligence; the passengers do not. ${ }^{96}$ The issue of contrilu-

93. Cf. Warren v. Parkhurst, 186 N.Y. 45. 7S N.E. 579 (1906).

94. E.g.. Liverpool \& London \& Globe Ins. Co. v. Clunie, \&S Fed. 160, 167 (C.C.N.D. Cal. 1S98) ; Stodder v. Rosen Talking Macl. Co., 241 Mass. 245, 249, 135 N.E. 251, 252 (1922) : United Mine Workers of America v. Red Jacket Consol. Coal \& Cuke Co.n 18 F.2d 839,848 (4th Cir. 1927) (in order to permit consolidation, sufficient grounds must appear that such a practice will promote the convenient administration of justice).

In National Hairdressers' and Cosmetologists' Ass'n v. Philad Co., 41 F. Sunp. 701 (D. Del. 1941), aff'd, 129 F.2d 1020 (3d Cir. 1942), the cuurt stated: "The relief granted to [plaintiff] and those on whose behalf his suit was brought should be completely effective and obviate the necessity or possibility of suits by [defendant] against members of the class represented by [plaintiff] based on alleged infringement of [a patent]." Id. at 708. The court, after declaring the patent invalid, added that: "Suits now pending brought by the defendant against members [of the class] will be enjoined as will the bringing of future infringement actions. . . . Such injunctive relief is sanctioned by the doctrine that a court of equity will act appropriately to prevent a multiplicity of suits." Id. at 708. Also see test laid down for the assumption of equity jurisdiction in Walleer v. Walker, 330 Mich. 332, 335-6 47 N.W.2d 633, 635 (1951).

95. See text at note 63 it siq. stipra.

96. Different degrees of duty may be owed to different claimants. Some may be invitees, licensees, or trespassers. See James, Tort Liability of Occupiers of Las:d: Dutics Ozied to Trespassers, 63 Yale L.I. 144 (1953). There also may be questions of contributory negligence. In re Texas City Disaster Litigation, 197 F.2d 771 (5th Cir. 1951), aff'd sub nom. Dalehite v. United States, 346 U.S. 15 (1953). See also James, Contributory Negligence, 62 Yale L.J. 691 (1953); James, Scope of Duly in Negligenee Cases, 47 Nw. U.L. Rev. 778 (1953) : Morris, Neyligence and Cansalion, 101 U. of PA. L. KET. 189 (1952). 
tory negligence is not common to all claimants, but it is common to an iclentifiable class of claimants. Instead of refusing to determine the contributory negligence question, the court of equity should allow two representative suits, one for employees and one for passengers. Thus the court would isolate the precise issues of law and make its determination binding only on claimants commonly interested in the issue. Only when this is clone can the bill of peace be effective. ${ }^{07}$

Apart from the operation of the "common interest" doctrine, the bill of peace is limited by jurisdictional, jury trial, and service of process doctrines. The bill was fathered by English equity, which did not have to cope with the dualism of federal and state jurisdiction. Here, federal courts hold that they have no power to enjoin state court actions in the mass tort situation. ${ }^{08}$ And a state court injunction can never be effective outside the territorial limits of the state. ${ }^{99}$ Hence an American court can entertain a bill of peace only to stay actions in its own jurisdiction.

Because the bill of peace procedure permits the judge to try issues of fact, ${ }^{100}$ it may run afoul of jury trial objections. When the bill of peace issues upon a showing of "common interest," the jury-less trial is probably warranted. At the time the federal and state constitutions were adopted. equity took jurisdiction in such circumstances. ${ }^{101}$ But a mere showing of multiplicity probably did not evoke equitable intervention at the end of the eighteenth century, and it certainly did not thereafter. ${ }^{102}$ Hence, an American court, even if it bypassed the "common interest" doctrine, would face a jury trial objection if it transferred legal actions to equity solely on the ground of multiplicity. ${ }^{103}$

The most serious obstacle to use of the bill of peace is the constitutional requirement of personal service of process. In an in personam action, the defendant must be served. ${ }^{104}$ Since a bill of peace restrains separate actions, it

97. See Pacific Fire Ins. Co. v. C. C. Anderson Co. of Nampa, 42 F. Supp. 917 (D. Idaho 1942).

98. E.g., Pennsylvania R.R. v. United States, 111 F. Supp. 80 (D.N.J. 1953).

99. See note 48 supra.

100. See text at note 63 stupra. A court of equity may, however, call upon the assistance of a jury to determine issues of fact. Crowell v. City of Riverside, 26 Cal. App. 2d 566, 80 P.2d 120 (1938); Commonwealth v. Smith, 344 Pa. 381, 25 A.2d 694 (1942).

In a court system where law and equity are merged, the tort-feasor might file a bill of peace in equity, but attempt to retain jury trial on the damage suits by simultancously beginning an action at law for declaratory judgment. Where this has been done, however, courts have granted the declaratory judgment but refused to entertain the request for injunctive relief. See pages $512-13$ infra.

101. See notes 73,74 supra.

102. See cases cited note 74 supra.

103. See Parkway, Inc. v. United States Fire Ins. Co., 314 Mass. 647, 651, 51 N.E.2d 436,438 (1943): "The controlling reason why the boundaries of general equity jurisdiction ought not to be widened by judicial decision beyond those indicated by established principles, is that the constitutional right of trial by jury would thereby become correspondingly narrowed." Also see Davis v. Forrestal, 124 Minn. 10, 144 N.W. 423 (1913). But see text at notes 23-4 supra.

104. See note 28 supra. 
would be entertained against claimants in the mass tort situation. ${ }^{105}$ The defendant who seeks a bill of peace will inevitably find service of process difficult. He may be unable to serve claimants not resident in the jurisdiction. ${ }^{100}$ Furthermore, claimants may remain anonymous until they file complaints. Lnquestionably a bill could be framed to restrain all claimants who file while suit is pending. ${ }^{167}$ But one who files after conclusion of the single suit-and hence had no "notice" of it-could not be barred from bringing a separate action. ${ }^{108}$ This problem is insubstantial if most people will file tort claims promptly. I3ut it might be profitable for a claimant to wait until the common litigation had produced a judgment. If the judgment were favorable, he could rely on stare decisis to reap the benents of it. If the decision were unfarorable, he could attempt to circumvent any barrier which stare decisis might impose. ${ }^{109}$ Thus, in any rnass tort case, it seems likely that many claimants will attempt to delay filing until at least one decision has been rendered.

\section{The Representative Suit: Spurious Class Actrons}

The spurious class action is a second method of simplifying mass litigation stemming from a single tort. ${ }^{110}$ Class actions were originally developed to circumvent the necessity of joining all indispensable members of a large class by permitting certain members of that class to represent others. ${ }^{111}$ In these cases, judgment was binding on all members of the class, whether or not they

105. See text at note 61 supra.

106. See test at notes 28 et seq. sipra.

The defendant may, in some instances, serve the claimant's attorney of record. But ts be valid, such service depends on (1) an enabling statute and (2) necessity. Keichner $v$ Mysinger, \&4 Tenn. 226, 198 S.W.2d 330 (1946). Compare Zeig v. Zeig, 65 Nev. 464, 198 P.2d 724 (1948).

107. Pacific Fire Ins. Co. v. C. C. Anderson Co. of Namp3, 42 F. Supp. 917 (D. Idaho 1912) (federal court enjoined prosecution of state court actions to grevent multiplicity as against the defendant insurers on identical policies, where the insurers requested an adjudication under the Federal Declaratory Judgments Act). But cf. Balier v. Atchison, T. \& S.F. Ry., 106 F.2d 525 (10th Cir. 1939).

108. Albrecht v. Bauman, 130 F.2d 452 (D.C. Cir. 1942) ; First Nat. Bank of Florence v. Edwards, 134 S.C. 348,132 S.E. 824 (1926).

109. See note $\$ 2$ supra.

110. For a general discussion of class actions, see Chares, ce. 6,7 ; Blume, The "Common Questions" Principle in the Code Procision for Representaliee Suits, 30 MIIch. L. REv. S7S (1932) ; Gordon, The Common Question Class Suit under the Federal Rules and in Illinois, 42 IrL. L. REv. 518 (1947) ; Kalven \& Rosenfield, sipra note 19; Keffee, Levy \& Donovan, sithra note 29; Moore, Federal Rules of Cizul Procedure: Sonce Problemus Raised by the Preliminary Draft, 25 GEo. L.J. 551 (1937).

111. In effect, many of the requirements for a class action are the same as those for the equitable bill of peace. Compare first two cases cited note 89 sipra, zill Montgomery Ward \& Co. v. Langer, 168 F.2d 182 (Sth Cir. 194S). But cf. Scott v. Donald, 165 U.S. 107 (1897). For the early English cases dealing with this problem, see City of London v. Richmond, 2 Vern. 421 n.1. (1701). For discussion of the transition hetween the bill of peace and the representative suit, see Chafee, c. 5; 3 Moone 3409-14. 
came before the court or had been served with process. ${ }^{112}$ Class actions were also utilized in situations where a common fund or property was in controversy. ${ }^{113}$ To insure adequate representation of the class' interests, the court could allow intervention. ${ }^{114}$

Federal Rule 23 codified both of these procedures and added one additional type of representative suit ${ }^{115}$-the spurious class action. ${ }^{110}$ This latter action is the only kind which can be used in mass tort litigation, and there is some indication that it was designed specifically with this end in view. ${ }^{117}$ In substance, the spurious class action is merely a provision for permissive joincler of parties-an invitation to those wishing to enter an action to do so. ${ }^{118}$

112. Supreme Tribe of Ben-Hur v. Cauble, 255 U.S. 356 (1921); Hartford Life Ins. Co. v. Ibs, 237 U.S. 662 (1915) ; Smith v. Swormstead, 16 How. 288 (U.S. 1853).

113. E.g., Women's Catholic Order of Foresters v. City of Ennis, 116 F.2d 270 (5th Cir. 1940), cert. denied, 313 U.S. 589 (1941). See also Terry v. Little, 101 U.S. 216 (1880).

114. In a true or a hybrid class suit, intervention is generally conditioned on a showing of inadequate representation, FED. R. Civ. P. 24(a) (2). So long as the original plaintiff is acting in good faith, the court will ordinarily deny the intervention. Ncw York $v$. New York Tel. Co., 261 U.S. 312 (1923) ; Gross v. Missouri \& A. Ry., 74 F. Supp. 242 (W.D. Ark. 1947); Owen v. Paramount Praductions Inc., 41 F. Supp. 557 (S.D. Cal. 1941). Where there is inadequate representation, however, the right to intervene is unquestionable. Park \& Tilford, Inc. v. Schulte, 160 F.2d 984 (2d Cir. 1947), cert. denicd, 322 U.S. 761 (1948) ; Klein v. Nu-Way Shoe Co., 136 F.2d 986 (2d Cir. 1943); Inuis, Speiden \& Co. v. Food Machinery Corp., 2 F.R.D. 261. (D. Del. 1942) ; Wolpe v. Poretsky, 144 F.2d 505 (D.C. Cir. 1944).

No problem of intervention should arise in the true class suit because each member of the class should by the very nature of the action be adequately represented by the plaintiffs. In the hybrid action, where specific property is involved, a person with a claim against that property is usually permitted to intervene. See 3 MOoRE, $\S \S 23.09,23.11$ (4).

115. FED. R. Civ. P. 23(a) reads as follows:

“(a) REPRESENTATION. If persons constituting a class are so numerous as to make it impracticable to bring them all before the court, such of them, one or more, as will fairly insure the adequate representation of all may, on behalf of all, sue or be sued, when the character of the right sought to be enforced for or against the class is

"(1) joint, or common, or secondary in the sense that the owner of a primary right refuses to enforce that right and a member of the class thereby becomes entitled to enforce it;

"(2) Several, and the object of the action is the adjudication of claims which do or may affect specific property involved in the action; or

"(3) Several, and there is a common question of law or fact affecting the several rights and a common relief is sought."

Rule 23 is not substantially different from former Equity Rule 38, except for the addition of subsection (a) (3). See Note, 55 Y ALE L.J. 831 (1946).

116. This name was given to this type of action by Professor Moorc. See Moore, Federal Rules of Cizil Procedure: Some Problems Raised by the Preliminary Draft, 25 Gro. L.J. 551 (1.937) ; 3 Moore $\$ 23.01$ et seq. For a criticism of the term, sce Kalven \& Rosenfield, supra note 19 , at 703 et seq.

117. See 3 MOORE 3443.

118. Schatte v. International Alliance of Theatrical Stage Employees, 183 F.2d 685 
By incorporating this procedural device in the federal rule, its proponents hoped to promote its widespread use as a method of alleviating hardship; individual litigation is costly in a world where group action dominates many commercial and social relationships. ${ }^{119}$ These hopes, however, have not been fulfilled..$^{120}$ Although the spurious class action is relatively new, the trend of judicial opinion concerning it has become crystallized to some extent. The cases have, in the main, drained the action of those features which promised to make its use in mass tort litigation revolutionary.

The case of Pennsylzania R.R. v. Vnited States ${ }^{121}$ illustrates graphically the limitations of the spurious class action. There, ammunition temporarily stored at Perth Amboy exploded. causing death, injury, or property damage to some eight thousand persons. ${ }^{122}$ The Pennsylvania was implicated as one of several alleged tort-feasors. ${ }^{123}$ It brought an action for a declaratory judgment to determine its legal responsibility. ${ }^{124}$ It named as defendants a representative group of claimants. ${ }^{125}$ other corporations which might have been responsible for the explosion, ${ }^{126}$ and the United States. ${ }^{127}$ Prior to this action,

(9th Cir. 1950) : Central Mexico Light \& Power Co. v. Munch, 116 F.2d 85 (2d Cir. 1940) : Bascom Launder Corp. v. Telecon Corp., 9 F.R.D. 677 (S.D.N.Y. 1950).

In a spurious class action, no one is bound but the actual plaintiffs. See text at note 137 et seq. infra. Thus it would seem that everyone should be given a right to intervene. There is, however, no absolute right of intervention. Loekwood v. Hercules Powder Co., 7 F.R.D. 24 (W.D. Mo. 1947).

119. See Keffee, Levy \& Donovan, supra note 29; Kalven \& Rosenfield, supra note 19. See also Comment, 46 CoL L. Rev. 818 (1946). But see 3 MToore 3470-2.

120. See Kalien \& Rosenfield, stspra note 19; Keffee, Levy \& Dunuvan, supra note 29.

121. 111 F. Supp. S0 (D.N.J. 1953).

122. Id. at $\$ 3, \$ 5$.

123. Id. at $81-2$.

124. Id. at $\mathrm{S1}$.

125. Ibid.

126. Possible defendants were identified in a public investigation which followed the disaster. Brief for Plaintiff in Support of Motion for Order Staying and Enjoining All Other Pending Actions, p. 1, Pennsylvania R.R. v. United States, 111 F. Supp. 80 (D.N.J. 1953) (hereinafter cited as Plaintrff's BRIEF).

127. Pennsylvania R.R. v. United States, 111 F. Supp. S0, 81-2 (D.N.J. 1953).

The Federal Tort Claims Act does not contain any language expressly prohibiting joinder of the United States with other defendants. Indeed, if anything, the Act's reference to the Federal Rules of Civil Procedure would seem to indieate that it was Congress" intent to permit joinder of defendants. See nute 5 supra. There may be practical dificulties in permitting a jury trial against the defendants other than the United States, while the latter is tried solely before the judge. See note 23 supra. However, these administrative difficulties have not been considered sufficiently formidable tu warrant dismissal of the case of an individual tort-feasor who had been joined with the United States. Englehardt v. United States, 69 F. Supp. 451 (D. Md. 1947) ; Bullock v. Unitcd States, 72 F. Supp. 445 (D.N.J. 1947) ; Brandt v. United States, 110 F. Supp. 627 (D. Guam 1953).

On the other hand, some courts have not permitted joinder of the United States with other defendants, influenced no doubt by the Supreme Court's decision in United States v. Sherwood, 312 U.S. 584 (1941). There it was held that under the Tucker Act, 60 Stat. 
many separate actions had been instituted in the courts of New Jersey, the situs of the alleged tort, in courts of other states, and in various federal district courts. ${ }^{228}$

The case was brought under Federal Rule 23(a)(3), the spurious class action provision. The railroad requested that the court's adjudication of the issues be made binding on all known and unknozen claimants. ${ }^{120}$ It also sought injunctive relief, contending that this was a case in which it was appropriate for the federal district court to restrain proceedings pending in state and other federal courts. ${ }^{130}$ The court denied both requests. ${ }^{131}$

Although the court in the Pennsylvania case propounded a questionable rationale, ${ }^{132}$ it conformed to precedent in refusing to enjoin separate actions. It is a long standing rule that, in diversity cases, state and federal in parsonam actions may run concurrently. ${ }^{133}$ The only possible authority for restraint is the federal court's statutory power to stay proceedings in a state court "where necessary in aid of its jurisdiction, or to protect or effectuate its judgment."134 But that statute sanctions injunctive relief only when it is "necessury" to preserve jursidiction or judgment. Courts have taken this to mean that state in personam proceedings can be enjoined only for the purpose of preventing re-litigation by the same parties of a controversy already decided in federal court. ${ }^{135}$ Under this interpretation, the sole justification for issuing an injunction is to save a former federal litigant, now defendant in state court, the trouble of pleading

842,28 U.S.C. $\$ 41(2)$ (1.946), a suit could not be maintained in a district court against the United States and another defendant. But the jurisdiction which the Tucker Act conferred on the district courts is only concurrent with that of the Court of Claims. And the Sherwood case involved a contract action. For a criticism of this decision, see 3 Moore II 1807. For examples of cases refusing joinder of defendants under the Federal Tort Clains Act, see Dickens v. Jackson, 71 F. Supp. 753 (E.D.N.Y. 1947) ; Uarte v. United States, 7 F.R.D. 705 (S.D. Cal. 1948). See also Drummond v. United States, 78 F. Supp. 730 (E.D. Va. 1948) ; Donovan v. McKenna, 11 F.R. Serv. 20a.14 Case 3 (D. Mass. 1948).

128. See Pennsylvania R.R. v. United States, 111. F. Supp. 80, 83, 85 (D.N.J. 1953).

129. Id. at 84 .

130. Id. at 88-9.

131. Id. at 91 .

132. The court relied in part on Toucey v. New York Life Ins. Co., 314 U.S. 118 (1941.), 27 CoRs. L.Q. 270 (1942), 26 Mins. L. Rev. 558 (1942), 20 Tex. L. Rev. 621 (1942), 90 U. of PA. L. Rev. 857 (1942). See also Barrett, Federal Injminctions against Proccedings in State Courts, 35 CaLIF. L. Rev. 545 (1947). This case was in effect overruled by Congressional legislation. See note 134 infra. In addition, Toucey involved a distinguishable fact situation. See text at note 136 infra.

133. Washington Loan \& Trust Co. v. Lyon, 98 F. Supp. 320 (D.D.C. 1951) ; see also note 40 supra.

134. 62 STAT. 968 (1948), 28 U.S.C. $\$ 2283$ (Supp. 1952); see also note 46 supra. This legislation repudiated the doctrine of Toucey v. New York Life Ins. Co., supra note 132.

135. E.g., Jackson v. Carter Oil Co., 179 F.2d 524 (10th Cir.), cert. denicd, 340 U.S. 812 (1950) ; First Nat. Bank \& Trust Co. of Racine v. Village of Stokie, 173 F.2d 1 (7th Cir. 1949); Moore's Commentary on the U.S. Judicial Code fl 0.03(49) (1949). 
and proving res judicata. ${ }^{136}$ Restraint of separate actions brought by a multitude of mass tort claimants is certainly precluded by such a view. Hence, all available precedent favors the Pconsyliania court's conclusion.

Only the most fragmentary precedent ${ }^{137}$ supports the railroad's second contention-that all claimants, including those unknown, should be bound by the decisions in a spurious class action. ${ }^{138}$ In fact, such a view seems to ignore constitutional service of process requirements. ${ }^{139}$ More frequently, courts have held such a judgment res judicata as to all parties properly notified of the suit. ${ }^{140}$ But even this is minority doctine. Despite some confusion, ${ }^{131}$ the overwhelming weight of authority agrees with the Pcmnsylvania court's holding that the decision in a spurious class action binds only those parties who have expressly signified an intent to enter the suit. ${ }^{142}$

Because the mass tort defendant can neither have non-assenting claimants bound by the judgment in a spurious class action nor force them to join the proceedings, the effectiveness of the procedure is limited. But it may have some utility. If the defendant can employ it to procure a decision before related litigation begins, he may discourage other suits or satisfy himself of the advisability of widespread settlement.143 For instance, a decision in the Pennsylvania case that the defendant's acts were not the legal cause of the explosion might have caused the abandonment of some separate suits. Conversely, faced with a decision that it was legally responsible, the railroad might have chosen to admit liability. ${ }^{144}$ It could then seek settlement where possible, or at least restrict future litigation to issues other than liability:

136. For examples of difficulties which arose prior to the statute, see Tourey $v$ New York Life Ins. Co., 112 F.2d 927 (Sth Cir. 1940) ; Phoenix Finance Corp. v. Iowa-Wisconsin Bridge Co., 115 F.2d 1 (Sth Cir. 1940). And those difficulties cuuld not be bypassed by framing the injunction to restrain the parties, rather than the state court. H.J. Heinz Co. v. Owens, 189 F.2d 505, 507 (9th Cir. 1951), cert. deried, 342 U.S. 905 (1952).

137. See Weeks v. Bareco Oil Co., 125 F.2d 84, 91 (7th Cir. 1941). There the court implied that a judgment in a spurious class action would be res judicata as to all members of the class, including those who had not assented to the litigation.

138. See Pennsylvania R.R. v. United States, 111 F. Supp. 80,90 (D.N.J. 1953).

139. See notes 29,30 supra. See also Kalven \& Rosenfield, supra note 19; Keffee, Levy \& Donovan supra note 29; Chafes, cc. $6,7$.

140. See cases cited in last paragraph of note 29 sifra.

111. See, e.g., Independence Shares Corp. v. Deckert, 108 F.2d 51 (3d Cir.), reviy 27 F. Supp. 763 (E.D. Pa. 1939), rerd, 311 U.S. 282 (1940), on remand, 39 F. Supp. 592 (E.D. Pa.), rco'd sub non. Pennsylvania Co. v. Deckert, 123 F.2d 979 (3d Cir. 1941). See also Weeks v. Bareco Oil Co., 125 F.2d S4 (7th Cir. 1941).

142. Cooper v. Goldsmith, 135 F.2d 949 (D.C. Cir. 1943); Albrecht v. Bauman, 130 F.2d 452 (D.C. Cir. 1942) ; Shipley v. Pittsburgh \& Lake Erie R.R., 70 F. Supp. 870 (W.D. Pa. 1947).

For the view that all members of a spurious class should be bound, whether before the court or not, see authorities cited note 119 supra.

143. See Communication to the Yale Law Jounnal from Mir. Gerald E Dwyer, General Attorney, New York Central System, dated November 13, 1953, in Yale Law Library.

144. Ibid. But see Communication to the Yale LaW Jougsal from Mir. Charles Cook 
The glaring inadequacy of the spurious class action appears, however, in the situation where the defendant has already been sued in several jurisdictions. Especially if different courts have reached different results, he faces problems. Presumably, the fact that decisions differ will make the defendant hesitant to settle claims en masse. Similarly, divergent decisions may do little to discourage potential plaintiffs. In such an event, the spurious class action does not lift the defendant out of the morass of multiple litigation.

Some states have adopted statutes patterned after Federal Rule 23.140 In such jurisdictions, the spurious class action clisplays the same shortcomings which attend its use in federal court. And state replicas suffer even more at the hands of service of process requirements. Not only can unknown claimants keep out of sight, but also known claimants not resident or present in the jurisdiction are immune from service. ${ }^{140}$

States which have not enacted the federal class action statute nevertheless entertain representative suits. A court usually decrees such an action when it finds that the claimants share a "common interest" and/or that the large number of the claimants makes it impracticable to join them all. ${ }^{147}$ In either case, the judgment normally binds all claimants. ${ }^{148}$ This procedure founders on objections

Howell, Vice-President and General Counsel of Atlantic Coast Line Railroad Company, dated July 1, 1.953, in Yale Law Library.

145. Aja. Code tit. 7, Rule 31 (App. 1940) ; Ariz. Code Ann. \$21-524 (1939); Colo. R. Civ. P. 23 (a) (1941); Iowa R. Civ. P. 42 (1951); N.J. R. Civ. Prac. 3.23 (1948); N.M. Stat. Ann. \$19-101 (23) (a) (1941); TEx. R. Civ. P. 42 (1941); Mich. CT. R. $16, \S 1$ (1945).

146. See notes $29-30$ supra.

147. The following states employ the "and/or" requirement. Alaska Comp. Laws AnN. §55-3-16 (1949); Ark. Dig. Stat. \$27-809 (1947); Cal. Code Civ. P. $\$ 382$ (Deering, 1949); Ind. Stat. Ann. §2-220 (Burns, 1933); Kan. Gen. Stat. §60-413 (Corrick, 1949); Minn. Stat. §540.02 (1945); Mont. Rev. Code ANN. \$93-2821 (Choate \& Wertz, 1947) ; Neb. Rev. Stat. \$25-319 (1943) ; Nev. Comp. Laws \$ 8558 (Hillyer, 1929) ; N.Y. Civ. Prac. Acr \$195 (1948); N.C. Gen. Stat. \$1-70 (1943); N.D. Rev. Code $\$ 28-0208$ (1943) ; Ohio Gen. Code $\$ 11257$ (Page, 1938); OkLn. Stax. ANn. tit. 12, $\$ 233$ (1938) ; ORE. CoMp. LAws ANw. $\$ 9-106$ (1940); S.C. Code $\$ 10-205$ (1952); Utah Code Ann. \$104-3-16 (1943); Wash. Rev. Stat. Ann. \$190 (Remington, 1932); Wis. Stat. \$260.12 (1951); Wyo. CoMp. Stat. § 3-616 (1945).

Some states categorically require both common interest and numerous parties. Fin. Stat. ANn. §63-14 (1943); Ga. Code § 37-1002 (1935).

For a criticism of the common interest test, see 3 MOORE 3417.

148. Swoope v. Darrow, 237 Ala. 692, 188 So. 879 (1939); International Brotherhood of Locomotive Engineers v. Mills, 43 Ariz. 379, 31 P.2d 971 (1934); Holthoff v. State Bank \& Trust Co. of Wellston, 208 Ark. 307, 186 S.W.2d 162 (1945); HowardSevier Road Improvement Dist. v. Hunt, 166 Ark. 62, 265 S.W. 517 (1924); Tetuney v. Miami Beach, 152 Fla. 126, 11 So.2d 188 (1942); Hopkins v. Jones, $193 \mathrm{Ky} .281,235$ S.W. 754 (1921) ; Kaufman v. Annuity Realty Co., 301 Mo. 638.256 S.W. 792 (1923); N.Y. State Railways v. Security Trust Co. of Rochester, 135 Misc. 456, 238 N.Y. Supp. 354 (Sup. Ct. 1929).

But cf. Weaver v. Pasadena Tournament of Roses Ass'n, 32 Cal. 2d 833, 198 P.2d 514 (1948); Haese v. Heitzeg, 159 Cal. 569, 114 Pac. 816 (1911). See also More v. 
which have been addressed to the equitable bill of peace. ${ }^{140}$ Certainly, mass tort claimants seldom share a "common interest" as most state courts define that term. ${ }^{150}$

Both the class action and the representative suit are more effective where the relief which claimants seek is an injunction or temporary restraining order. ${ }^{151}$ The fact that the federal procedure is permissive in nature is of less importance. At least a decision imposing restraint will whriate further litigation. And state courts are more liberal in finding a "common interest" among claimants requesting injunctive relief. ${ }^{152}$ But praying for equitable relief

Western Conn. Title \& MItg. Co., 128 Conn. 360, 23 A.2d 128 (1941) (judgment could not be res judicata, since there was a conflict of interests wer whether property should be sold; court required proper notice to all, so that those with adverse interests could appear).

149. See pages 506-09 supra.

150. See, e.g., Weaver v. Pasadena Tournament of Roses Ass'n, 32 Cal. $2 \mathrm{~d} 833$, 840 , 198 P.2d 514, 518 (1948): "[I]ndependent research has failed to reveal a single ease in which it has been held that a representative ar class suit was a proper or appropriate vehicle for the determination of alleged tort liahility of defendants to numerous named or unascertained persons."

In United Mine Workers of America v. Bourland, 109 Ark. 796, 277 S.W. 546 (1925), the court held that the doctrine of representation is inaplicable in a suit against a union, since equity would not take jurisdiction over a case imviving a cuestiun of unliquidated damages arising from a tort. See also Baskins v. Uniter Mine Workers of America, 150 Ark. 398, 234 S.W. 464 (1921).

The following cases are general examples of state judicial interpretation of the community of interest and the impracticability of joinder tests: IVeaver v. Pasadens Tuurna* ment of Roses Ass'n, supra; Peterson v. Donelley, 33 Cal. App. 2d 133, 91 P.2d 123 (1939) (community of interest found among beneficiaries of a voting trust); Coachella Valley County Water Dist. v. Stevens, 206 Cal. 400, 274 Pac. 538 (1920) (c.mmunity of interest rather than necessary party test): Parker v. Lniversity of Delaware, 31 Del. Ch. 381, 75 A.2d 225 (Ch. 1950) (Delaware Negroes legally interested in a determination of their constitutional rights concerning admission to college constitute a class); Allen v. Avondale Co., 135 Fla 6, 185 So. 137 (1938) (in suit by purchaser of one of 1000 subdivided lots, to remove restrictive covenants, the defendant property owners constituted a class); Macon \& B.R.R. v. Stamps, 85 Ga. 1, 11 S.E. 442 (1890) (citizens of a town, as representatives of a class, may sue to prevent the city in its corporate eapacity from using city funds for the construction of a railroad) ; O'Jay Spread Co. v. Hicls, 185 Ga. 507, 195 S.E. 564 (1938) (the fact that the individual interest of the plaintiffs may in some respects differ, or that all do not have an interest in all matters embraced in the litigation, will not render the petition multifarious as to the individual plaintifis, or subject it to attack for misjoinder of parties or causes of action, if each of the plaintifis has an "essential" interest). But see Webb \& Martin Inc. v. Anderson-MIcGriff Hardware Co., 183 Ga. 291, 3 S.E.2d 882 (1939). See also note 29 supro.

151. E.g., McNutt v. General Motors Acceptance Corp., 298 U.S. 178 (1936); Healy v. Ratta, 292 U.S. 263 (1934); Grand Rapids Furniture Co. v. Grand Rapids Furniture Co., 127 F.2d 245 (7th Cir. 1942) (trade name infringement); cf. Rogers v. Hennepin County, 239 U.S. 621 (1916). See also Brown v. Trousdale, 138 U.S. 389 (1S91) (assertion of a public right). But cf. California Apparel Creators v. Wieder of California, Inc., 162 F.2d 893 (2d Cir.), cert. denicd, 332 U.S. 816 (1947).

152. See, e.g., San Francisco v. Market Street Ky., 95 Cal. App. $2 d$ 648, 213 P.2d 780 (1950); Fallon v. Superior Court, 33 Cal. App. 2d 48, 90 P.2d 858 (1939); Jellen v. 
may cause a state court to interpret the action as one requiring application of bill of peace doctrines. In that event. claimants may hit snags which inhere in that procedure. ${ }^{153}$

\section{Receivership Proceedings}

One Connecticut case originated a novel method for treating mass tort claims. ${ }^{15 t}$ Because in that state a tort claimant can attach property of the defendant's when he files suit, allowing separate actions at law would have doomed the defendant to bankruptcy. ${ }^{155}$ At the request of a selected claimant, the defendant's business was placed in the hands of a receiver. ${ }^{160}$ The receiver operated the business, building up reserve funds to pay legitimate claims in full. ${ }^{157}$ The defendant waived all affirmative defenses, and disputes were submitted to arbitration, by which the parties agreed to be bound. ${ }^{158}$ In most jurisdictions, however, such a procedure must stem from consent. Every state but three denies a non-judgment creditor standing to throw a person into receivership. ${ }^{150}$ Furthermore, consent is unlikely in most cases. Only in states where attachment may precede suit can the defendant be expected to accept the stigma of receivership. Otherwise, with his property free of attachment, the defendant can continue to operate his business during the trial period, setting aside reserves to satisfy claims established in court. And where the defendant does this, claimants will probably prefer jury trial to arbitration.

\section{Consolidation and Pre-Trial Conierence}

Perhaps the most promising system for handling mass tort litigation has developed recently in federal procedure through the combined use of pre-

O'Brien, 89 Cal. App. 505, 264 Pac. 115 (1928) ; Lindsay-Strathmore Irrigation Dist. v. Superior Court, 182 Cal. 315, 187 Pac. 1056 (1920) ; Smith v. Delaware Coach Co., 31 Del. Ch. 256, 70 A.2d 257 (Ch. 1949); New Mission Baptist Church v. Atlanta, 200 Ga. 518, 37 S.E.2d 377 (1946) ; Kimsey v. Mickel, 191. Ga. 158, 12 S.E.2d 567 (1940) ; McIntyre v. Harrison, 172 Ga. 65, 157 S.E. 499 (1931). Contra: Watson v. Santa Carmelita Mut. Water Co., 58 Cal. App. 2d 709, 137 P.2d 757 (1943) ; Material Service Corp. v. McKibbin, 380 I1l. 226, 43 N.E.2d 939 (1942).

153. See pages 506-09 supra.

154. See Note, The Equity Receivership in Mass Tort, 60 YAle L.J. 1417 (1951) (commenting upon the Ringling Bros., Barnum \& Bailey circus fire in Hartford, Connecticut).

155. Id. at 1418 n.6.

Bankruptcy was inevitable because the total value of the claims asserted was greater than the defendant's assets. In addition, defendant's property had no earning capacity while frozen by attachment. Ibid.

156. Id. at $1418 \mathrm{nn} .8-10$.

157. Pursuant to an agreement among the parties, the assets of the circus were released during the period of arbitration. Id. at 1419.

158. Id. at 1419 n.12.

159. E.g., Pusey \& Jones Co. v. Hanssen, 261 U.S. 491 (1923). See Note, 60 YalsE L.J. $1417,1420-5$ (1951). 
trial conferences ${ }^{160}$ and consolidation of actions under Federal Rule $\left.42(a)\right)^{101}$ The method has achieved particular success in litigation governed by a short statute of limitations, such as that embodied in the Federal Tort Claims Act. ${ }^{102}$ In a recent case, Clark 2. ' 'nitcd States, ${ }^{103}$ the procedure was used to good advantage. Here, the parties agreed to delay the trial of all actiuns until the two-year statute of limitations had run. ${ }^{164}$ Even if agreement had not been reached, the court could probably have delayed trial that long. Before the limitations period expired, some seven hundred suits were filed against the Government for damage caused by the collapse of a river embankment built by the Government. ${ }^{100}$ A total of ninety-one lawyers represented various claimants. ${ }^{106}$ At a meeting, these attorneys selected a cummittee of three lawyers to handle the trial and pre-trial work. ${ }^{163}$

This litigation was not a class action. Although the feasibility of the clas, action device was debated at a pre-trial conference, it was decided that class action was impossible: it was questionable whether any group of plaintiffs under the Tort Claims Act could join in class litigation. ${ }^{108}$ Instead, the actions were consolidated.

160. For general discussion of pre-trial, see Duuglas, Pre-Trial Procedture, 26 A.B. A.J. 693 (1940) ; Fee, The Lost Horizon in Plicading under the Federal Rules of Cizil Procedure, 48 CoL. L. Rev. 491 (1948); Fisher, Itdicial IIcdiation-Hosw it Worlss Through Pre-Trial Conference, 10 U. of CHI. L. Rev. 453 (1943); Murrah, A Pre-Trial Procedure: A Statement of Its Essentials, 14 F.R.D. 417 (1953).

161. FEv. R. CIV. P. 42(a):

"Consolidation: Separate Trials.

“(a) CONSOLIDATION. When actions involving a common question of law or faet are pending before the court, it may order a joint hearing or trial of any" ur all the matters in issue in the actions; it may order all the actions consolidated; and it may make such orders concerning proceedings therein as may tend to avoid unnecessary costs or delay."

162. 63 Stat. 62 (1949), 2S U.S.C. \$2401(b) (Supp. 1952).

163. 13 F.R.D. 342 (D. Ore. 1952).

164. Id. at 343 .

165. Ibid.

166. Communication to the Yale Law Journal from Mr. Ray G. Brown, Chairman of the Committee of Claimants' Lawyers, dated April 21, 1953, in Yale Lav Library.

167. Ibid.

168. Exactly why this should be so is unclear, since the Federal Tort Claims Act expressly provides that the courts are to follow the Federal Rules of Civil Prosedure. 60 Stat. 843-4 (1946), $2 \$$ U.S.C. $\$ 1346(6)$ (Supp. 1952). In fact, it appears that it was Congress' intent to expedite the final settlement of all claims by including in one action all parties directly concerned, despite technical objections to such joinder which previously might have been made. Englehardt v. United States, 69 F. Supp. 451 (D. MId. 1947). Perhaps the doubt may have been occasioned by the fact that there is sume controversy over whether the United States may be joined with other defendants in an action under this Act. See note 127 supra.

Certainly consolidation and extensive use of pre-trial procedure was far more effective than a class action would have been. Probably there could not have been a true class action in the present fact situation, and there was no way in which to force party litigants to join in a spurious class action. See text at note 118 supro. 
Pre-trial conferences were also employed. ${ }^{169}$ These conferences were held in open court and recorded by a reporter. Many plaintiffs were present. 170 Eventually, twenty cases of the entire group were selected for trial.171 To assure a complete determination of all issues concerning liability, the court directed each plaintiff whose case was not selected for trial either to draft a proposed pre-trial order describing the issues of liability in his particular case, or else to agree of record to accept the issues of liability set out in the principal pre-trial order. If the plaintff chose neither of these alternatives. his case was dismissed for failure to prosecute. ${ }^{172}$

In order to gain further assurance that all possible isstes of law and fact would be litigated, the court twice reviewed briefs submitted by attorneys for the various plaintiffs and ordered an oral argument covering the entire field of liability. ${ }^{173}$ This seems to have been successful in framing issues and in facilitating the stipulation of many evidentiary facts not brought out in the pleadings.

The effectiveness of the procedure in Clark was enhanced by two facts. First, the judge was willing to make extensive use of the pre-trial conference and to use every power at his command to force the parties to litigate model suits. Secondly, the federal court had exclusive jurisdiction over the parties' actions, since they were brought under the Federal Tort Claims Act. ${ }^{17.4}$ Malss tort litigation over which the federal courts do not have exclusive jurisdiction does not lend itself so readily to effective consolidation; here again the fact that federal courts find themselves unable to enjoin state actions emasculates the procedural device. But consolidation at least avoids one of the problems raised when the class action is used. Service of process requirements do not intrude as much. By deferring trial until the statute of limitations ran, the Clark court eliminated that troublesome creature, the unknown claimant. No one could file a valid claim after the limitations period had run.

169. Clark v. United States, 13 F.R.D. 342, 343-7 (D. Ore. 1952).

170. Id. at 343 .

171. Id. at 344 .

172. Ibid.

173. Ibid. The court also made a final review in order to avoid Rule $15(\mathrm{~b})$, which states that issues not raised by the pleadings are considered to have been tried through the implied consent of the parties, and shall be considered as if they had been raised by the pleadings. FED. R. CIV. P. 15(b). The unfairness of this rule should be apparent in a case of this nature, where model suits are being used. If an issue not raised in the pleadings was deemed to have received an implicit adjudication, all would be bound. In order to avoid this contingency, the court found that the issues set out in the pre-trial order were the only ones tried, whether of fact or of law. The court further stated that "if someone hereafter conceives that other issues were tried, the proper result would be to send the case back for the trial of those issues rather than assuming that such issutes were tried." Clark v. United States, supra note 169, at 344.

174. 60 SтAT. 842 et seq. (1946), 28 U.S.C. $\$ \$ 1291,1346,1402,1504,2110,2401,2402$, 2411, 2671-80 (Supp. 1952). See note 127 supra. 
State laws permitting consolidation are often less litseral than the federal rules. They often require that consolidation be limited to the consolidation of multiple actions between the same parties. ${ }^{17 \pi}$ Even where state laws put consolidation beyond reach, however, use in state court of the pre-trial conference may be effective to a degree. ${ }^{170}$ In one case arising out of a series of wrecks on the Long Island Railroad, the Supreme Court of New York pre-tried two hundred cases in eleven days. ${ }^{177}$ This was not the usual pre-trial procedure, since no effort was made to narrow the issues, amend the pleadings, or obtain stipulations. ${ }^{178}$ Because of public resentment centering on the accidents, the issue of liability was not open to serious dispute. ${ }^{170}$ The primary concern was to ascertain the extent of each claimant's damages. This the opposing lawyers worked out for themselves, eliminating unrealistic claims and effecting many settlements. ${ }^{180}$ Here, it is true, the pressure of public opinion may have forced many concessions. ${ }^{\text {IS1 }}$ It was also true that nothing more was accomplished than might have been done by the defendant itself prior to the pre-trial conference. ${ }^{182}$ Nevertheless the impartial influence of judicial sponsorship and supervision may have facilitated roluntary settlement. At least such a procedure helps to free the courts and the parties from the load of unnecessary litigation. ${ }^{183}$ Where there is pressure to settle, the pre-trial conference may in itself be a potent tool for eliminating unneeded controversy.

\section{Conclusion}

In evaluating the three major devices for simplifying mass tort litigationthe bill of peace, the spurious class action, and the combination of consolidation and pre-trial conference-the extent to which each device aids the defendant must be balanced against the degree to which it prevents each claimant from obtaining a full hearing. The bill of peace favors the turt-feasor. It forces all claimants against whom the bill issues to abide by a single decision. Furthermore, the traditional practice of determining issues in a single representative suit in equity gives plaintiffs little chance to choose the manner in which their claims will be argued. ${ }^{184}$ The only saving grace from the claimant's point of view is that the bill cannot be entertained against him as long as he is un-

175. E.g., Bley v. Travelers Ins. Co., 27 F. Supp. 351,357 (S.D. Ala 1939).

176. See Cray, The Pre-Trial in Action, 37 Iowd L. Rev. 341 (1952); Kincaid, PreTrial in Our Supreme Court, 27 J. State Bas of Cauff. 255 (1952); Louisell, Discowary and Pre-Trial under the Mintiesota Rules, 36 MInN. L. Rev. 633, 660 (1952).

177. Ajserican Bar Ass'in, Refort of Comomitee on Pre-Trial Procenume to Section of Judicial Adarinistrition (copy in Yale Law Library).

178. Ibid.

179. Ibid.

180. Ibid.

181. Ibid.

182. Ibid.

183. Ibid. See also Murrah, supra note 160 , at 420 .

184. See Chafee 183 et seq. 
known to the defendant. ${ }^{185}$ And that very fact limits the bill's utility to defendants. As a practical matter, also, relief through bills of peace nay be hard to procure. Allowing trial of damage actions by a jury-less court, while it may not violate constitutional provisions, runs contrary to a long American tradition. ${ }^{1 \mathrm{Nu}}$

The spurious class action, on the other hand, is solicitous of claimants' rights. A decision in such an action cannot bind plaintiffs who do not agrec to be bound. And even where a claimant has so agreed, the court may allow him to protect his interests by intervening. ${ }^{187}$ In addition, this procedure preserves jury trial. But, in safeguarding claimants, the spurious class action denies the defendant any certain benefit. He cannot force claimants to enter the action or to become bound by its outcome. Intervention may destroy the simplicity of the suit. Most important, this procedure, like the bill of peace, fails to cope with the problem of unknown claimants.

In contrast to both of the foregoing systems, the combination of consolidation and pre-trial conference seems to strike a fair balance between the interests of claimants and defendants. It offers the defendant a means of binding all parties, if not to one decision, at least to one group of decisions renclered in the same suit. ${ }^{188}$ As employed in the Clark case, the procedure avoids the unknown claimants problem by delaying trial until the limitations period has run. Even if trial is commenced before that time, claimants' suits can be incorporated as they are filed. At the same time, judge-supervised use of the pre-trial conference affords each claimant a fair opportunity to present his own legal and factual interpretations. ${ }^{180}$ For these reasons, the consoli-

185. See text at note 108 supra.

186. See notes 74,103 supra.

187. See note 14 supra. The privilege of being represented by counsel not of one's own choosing, however, is not absolute in a representative suit. E.g., Schatte v. International Alliance of Theatrical Stage Employees, 183 F.2d 685, 687 (9th Cir. 1950) : "The general rule in class suits is that the member of the class who is the original plaintiff retains control over the action as opposed to other members of the class who may later seek to intervene."

188. See communication to the Yale LAw Journal, from Warren E. Burger, Assistant Attorney-General, Civil Division, United States Department of Justice, dated April 28,1953 , in Yale Law Library.

But see Dalehite v. United States, 346 U.S. 15 (1953). In that case a question arose as to the finality, for purposes of appeal, of the judgments in a large number of consolidated actions. These actions were being litigated through the expedient of a test case. On appeal, all judgments, except the one in the test case (Dalehite v. United States, supra), were not considered final; by the terms of the pre-trial order, the Government had retained the privilege of litigating all affirmative defenses, in addition to the amount of damages in every non-litigated case. See communication to the YALE LAW JounNAr from Mr. Stuart Thayer, supra note 3. The case illustrates the care with which pre-trial orders must be drawn to prevent extended litigation of issues which could be settled in a single proceeding.

189. In this context, the pre-trial conference will be ineffectual unless it embraces the issues raised by all or nearly all of the claims arising from the mass tort. Because use of the pre-trial in the mass tort situation is new, lawyers may balk at plunging their 
dation and conference procedure is preferable to both the bill of peace and the spurious class action. ${ }^{130}$

Regardless of how justly the procedural devices reconcile defendants' and claimants' conflicting interests, their usefulness is limited by current dactrines. No court can issue service of process in an in personam action to a non-resident outside its jurisdiction. ${ }^{191}$. And no court can effectively enjuin an in personam action pending in another jurisdiction. ${ }^{102}$ Despite these limitations, procedural devices can achieve some simplification of mass tort litigation. Frequently, many claims stemming from one tort are filed in a single jurisdiction. ${ }^{193}$ By taking advantage of procedural simplitication in each jurisdiction, the mass tort defendant could at least reduce the number of suits to one per jurisdiction. But even then the defendant may face the burdensome task of defending several complex suits, and those suits may still produce different results.

In order to approach their goal of obtaining a complete adjudication in one proceeding. mass tort defendants must look to Congress. ${ }^{104}$ The limitations presently imposed on state jurisdiction are constitutional; no legislation can remove then. ${ }^{195}$ But the present limits of federal court puwer are set

clients" claims into such a procedure. The Clark court dealt with hesitancy by dismissing claims of those who refused to participate in pre-trial conference. See text at notes 171-2 supra. Should a court consider dismissal tow drastic, it could still coerce uncooperative parties by taxing them for the costs sustaitied by their opponents and attributable to litigation of issues which should have heen stipulated at the pre-trial stage. But dismissal does not seem unduly harsh, in light of the opportunity given to claimants to make their own arguments at the pre-trial pruceedings. See text at notes 172-3 supra.

190. Courts might obviate the unknown claimant's problem in the bill of pease procedure by delaying the single suit until the limitations nericd runs-just as the Clarl: case did. But no bill of peace case has been found in which this was done. And, unlike the bill of peace, the consolidation procedure preserves jury trial, in accordance with American judicial policy. See note 20 sufra. In addition, the bill of peace does not protcet claimants' rights so fully. See page $50 \mathrm{~S}$ supra.

191. See notes 30-1 suspra.

192. See note 48 supra.

193. See, e.g., In re Texas City Disaster Litigation, 197 F.2d 771 (5th Cir. 1951), aff'd sub nom. Dalehite v. United States, 346 U.S. 15 (1953).

194. "The Federal Rules of Civil Procedure and existing legislation do nut provide a satisfactory solution of the problems presented by the legal controversies arising out of accidents such as the South Amboy explosion. They are controversies in which the common questions of law and fact should be tried in une action in which every individual and corporation accused of liability and the United States could be joined, in which all claimants could be represented and in which all the evidence could be presented. Such a result, however, cannot be achieved unless Congress modifies, in this unusual type of situation, the requirements of complete diversity of citizenship, allows service of summons outside of the district wherein the court hearing the case sits, and permits a federal court to enjoin all other suits arising out of the same occurrence." Pennsylvania R.R. v. United States, 111 F. Supp. 84, 91 (D.N.J. 1952).

195. There is one exception. Absent statutory authority, most state courts hold that they are not bound to respect an injunction issued by another state. Sce Giviracu, of. cir. 
by statute. If it wished, Congress could grant federal courts the authority to enjoin concurrent in personam actions pending in state courts. ${ }^{100}$ And it could provide that in the mass tort situation service of process will be valid throughout the United States, not merely in the district of the court in which the action was brought. ${ }^{197}$ By making these statutory clanges, Congress would pave the way for determination in one proceeding of almost all claims resulting from a mass tort.

Some claims, of course, should be left to the states. Most mass tort claims will be subject to federal jurisdiction because the parties have diverse citizenship. But state courts should adjudicate claims where there is no requisite diversity among any of the parties or other ground for federal juriscliction. Moreover, stanclard conflicts of law doctrine requires all courts to apply the law of the state where the tort was committed. ${ }^{198}$ And the Eric doctrine binds federal courts to respect state conflicts rules in diversity cases. ${ }^{100}$ Hence where federal jurisdiction is based on cliversity and the law of the state of the tort is unsettled, it would seem wise to allow at least one suit to proceed in that state. But apart from these limited exceptions, congressional action can pave the way for speedy and economical, yet equitable, litigation in one fecleral proceedling of all the claims stemming from a mass tort.

supra note 51 , at 642 n.148. Presumably, widespread state legislation could effectuate a uniform system of reciprocal enforcement. But such a possibility seems remote. And state courts would still be hampered by constitutional doctrines concerning service of process.

196. Howard v. United States, 126 F.2d 667, 668 (10th Cir.), (crt. denicd, 316 U.S. 699 (1942), discussed in note 30 supra.

197. See note 30 supra.

198. Goodrich, op. cit. supra note 51, c. 6.

199. Id. at 33-45.

200. The alleged tort may involve as yet unresolved issues of law of the state of the tort's situs, or issues which though already adjudicated in that state are suspect since subesquent decisions have given every indication that if again presented to that state's highest court, those very issues would be decided differently. For examples of the guessing game federal judges must play when Erie bids them to respect state law but state precedent is equivocal or lacking, see King v. Order of United Commercial Travelers, 333 U.S. 153 (1948); Sunbeam Corp. v. Civil Service Employees' Cooperative Ass'n, 187 F.2d 768 (3d Cir. 1951). Apparently, the game will end only upon an authoritative decision by the state's highest court. See Cooper v. American Air Lines, Inc., 149 1*.2d 355 (2d Cir. 1945). 